\title{
Spatiotemporal patterns of sediment deposition on the northern slope of the South China Sea in the last 150,000 years
}

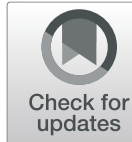

\author{
Zhe Hu' ${ }^{1}$, Bao-Qi Huang ${ }^{* *}$ (D), Le-Jun Liu² and Na Wang ${ }^{3}$
}

\begin{abstract}
The source-to-sink system of the northern South China Sea (SCS) has been widely discussed during the past few decades. Sr-Nd isotope, clay minerals and trace elements were extensively used as the proxies of sediment provenance, however, still little is known about the transport processes and controlling mechanisms on detailed spatiotemporal scales due to the limitations of these methods. Here we put forward the new provenance proxies $R_{A K}$ and $R_{K C N}$ based on major element compositions to study the spatiotemporal changes in sediment provenance since 150 ka mainly from four sites, DLW3101, MD12-3429, ZHS-176 and MD12-3432, which are located on the northern SCS continental slope. Our results show that, spatially, the pathways and intensities of contour currents and gravity flows play important roles in sediment transport. For alongslope processes, the South China Sea Branch of Kuroshio Current (SCSBKC) and the Deep Water Current (DWC) transport sediments from southwestern Taiwan, while the Intermediate Water Current (IWC) can carry sediments from Hainan, the Red River or the Indochina Peninsula. For downslope processes, gravity flows transport materials from the Pearl River delta and shelf to the slope. Moreover, seafloor bathymetry influences sediment transport by altering the pathways of ocean currents. Temporally, the impacts of sea level and monsoon rainfall fluctuations are always superimposed over the last 150 ka. Sea level fluctuations could significantly change the distance from the Pearl River estuary to the slope, while variations in the East Asian summer monsoon (EASM) rainfall would affect continental erosion rates in the source regions.
\end{abstract}

Keywords: South China Sea, Sediment transport, Element composition, Ocean current, Sea level, Quaternary

\section{Introduction}

The South China Sea (SCS) is an excellent case setting for fluvial sediment source-to-sink transport process studies (Liu et al. 2016). Nearly $7 \times 10^{8}$ metric tons of sediments are deposited in the SCS every year, of which approximately $80 \%$ come from surrounding rivers, such as the Pearl River and rivers in southwestern Taiwan and Luzon (Huang and Wang 2006; Liu et al. 2008, 2016). The Pearl River contributes approximately $80 \mathrm{Mt} / \mathrm{a}$ of fluvial sediments to the SCS (Fig. 1) (Milliman and Farnsworth

\footnotetext{
* Correspondence: bqhuang@pku.edu.cn

${ }^{1}$ Key Laboratory of Orogenic Belts and Crustal Evolution, MOE, School of

Earth and Space Sciences, Peking University, Beijing 100871, China

Full list of author information is available at the end of the article
}

2011), mostly deposited on the inner shelf between the Pearl River mouth and Hainan (Fig. 1) (Liu et al. 2013; Wang et al. 2013; Ge et al. 2014). Luzon-sourced sediments ( $11 \mathrm{Mt} / \mathrm{a})$ (Milliman and Farnsworth 2011) generally accumulate northwest of Luzon (Fig. 1) (Liu et al. 2011). Meanwhile, southwestern Taiwan supplies $\sim 70$ Mt/a sediments to the northern SCS (Fig. 1) (Milliman and Farnsworth 2011), transported westwards by contour currents (Wan et al. 2010a; Hu et al. 2016; Liu et al. 2017).

The various source-to-sink processes contribute to different clay mineralogical and geochemical characteristics, due to the diverse material compositions of the fluvial sediments around the SCS (Liu et al. 2016). The sediment provenance change has been discussed by 


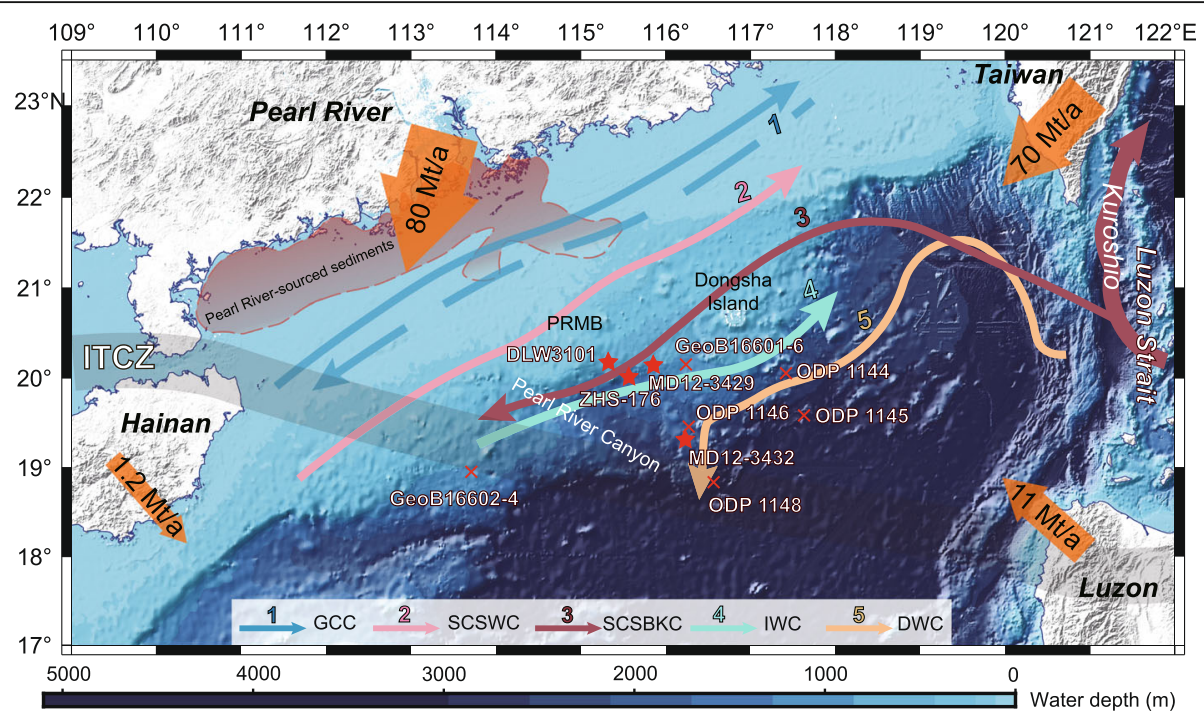

Fig. 1 Bathymetric map and the locations of the sites referred to in this study. The study sites DLW3101, MD12-3429, ZHS-176 and MD12-3432 are marked with red pentagrams. The locations of other sites discussed in the text are also indicated, including GeoB16602-4 and GeoB16601-6 (Liu et al. 2017), and Ocean Drilling Program (ODP) sites 1144, 1145, 1146 and 1148 (Boulay et al. 2005; Wei et al. 2006; Shao et al. 2007; Wan et al. 2010a). The annual sediment discharges of potential sources are indicated by orange arrows (Milliman and Farnsworth 2011). Red shaded area depicts the dispersal of Pearl River-sourced sediments in the Holocene (Ge et al. 2014). Gray ribbon shows the location of the Intertropical Convergence Zone (ITCZ) (Clift 2006). 1: Guangdong Coastal Current (GCC, blue arrow and blue dashed arrow, from Liu et al. 2010); 2: South China Sea Warm Current (SCSWC, pink arrow, from Wang et al. 2010, and Liu et al. 2011); 3: South China Sea Branch of Kuroshio Current (SCSBKC, crimson arrow, from Qiu et al. 2011, Luan et al. 2012, and Nan et al. 2015); 4: Intermediate Water Current (IWC, cyan arrow, from Wang et al. 2013); 5: Deep Water Current (DWC, almond arrow, from Shao et al. 2007). PRMB: Pearl River Mouth Basin; Mt: million metric tons

many different proxies, such as Sr-Nd isotope, trace elements and clay minerals (Shao et al. 2008; Hu et al. 2012; Wei et al. 2012; Liu et al. 2016). Based on clay minerals, Liu et al. (2017) found that site GeoB16602-4 (water depth: $970 \mathrm{~m}$ ) on the west side of the Pearl River Mouth Basin (PRMB) (Fig. 1) received more detrital materials from the Pearl River during the Last Glacial Period (LGP), whereas site GeoB16601-6 (water depth: $1012 \mathrm{~m}$ ) on the east side (Fig. 1) always got a higher fraction of detrital materials from Taiwan both in glacial and interglacial. Below the lower slope, the clay mineral assemblages at Ocean Drilling Program (ODP) site 1145 (water depth: $3175 \mathrm{~m}$ ) show no significant variation during glacial-interglacial cycles (Boulay et al. 2005), in contrast to those at MD12-3432 (water depth: $2125 \mathrm{~m}$ ) and ODP site 1146 (water depth: $2092 \mathrm{~m}$ ), where the influence of the Pearl River input enhanced during glacials (Liu et al. 2003a; Chen et al. 2017a).

Previous studies were often limited to individual sites or specific depth ranges on glacial-interglacial cycles (Liu et al. 2003a, 2017; Huang et al. 2016; Chen et al. 2017a), and little is known about what happens on other timescales and larger spatial ranges. Otherwise, information on provenance changes contained in major element compositions has hardly been exploited. Since the $\varepsilon_{\mathrm{Nd}}$ values of modern Taiwan (Chen and Lee 1990; Lan et al. 2002), modern Pear River drainage basin sediments (Liu et al. 2007) and Holocene Pearl River estuary (Hu et al. 2013) are similar, the differences in clay mineral contents can only illustrate the fine-grained portion, and the trace elements can be easily altered by diagenesis or biochemical processes (Tribovillard et al. 2006), a critical synthesis of provenance proxies derived from major element data is desperately needed.

In this study, we generate major element and clay mineral data mainly from four cores on the northern SCS slope encompassing the full depth range over the last $150 \mathrm{ka}$. Based on the major element compositions, we utilized the new proxies $R_{A K}$ and $R_{K C N}$ to indicate the provenance change on the whole slope. Besides, the $\mathrm{Sr}-$ $\mathrm{Nd}$ isotope, oxygen isotope of speleothem, grain size, insolation and global sea level data are also shown to identify the spatiotemporal changes in sediment provenance and transport processes, and discuss the controlling mechanisms.

\section{Regional setting}

The SCS is the largest marginal sea in the western Pacific, while the latitude range spans from $0^{\circ}$ to $23^{\circ} \mathrm{N}$. The temperature distribution of SCS largely follows the latitudinal zonality of climate at the Earth's surface (Liu et al. 2016). The East Asian summer monsoon (EASM) controls seasonal precipitation around the SCS (Chen et al. 2017a), and the strongest rainfall region migrates 
together with the Intertropical Convergence Zone (ITCZ) (Fig. 1) (Clift 2020). The EASM is believed to have been stronger during interglacial (Wan et al. 2017), and the mean ITCZ shifts are likely less than $1^{\circ}$ even during the Last Glacial Maximum (LGM) (McGee et al. 2014). In principle, the heavier rainfall is expected to have a major influence on the river run-off and denudation intensity around the source regions (Liu et al. 2003b; Zhong et al. 2017).

After entering the SCS, the sediment particles are transported both alongslope and downslope to the northern slope by currents (Zhong et al. 2017; Wang et al. 2018a). Along the slope, there are three contour currents at different water depths (Fig. 1): the westward South China Sea Branch of Kuroshio Current (SCSBKC, $<500 \mathrm{~m}$ ) (Shaw and Chao 1994), the eastward Intermediate Water Current (IWC, 500-1500 m) (Zhu et al. 2010; Gong et al. 2013; Wang et al. 2013; Chen et al. 2014) and the westward Deep Water Current (DWC, > $2000 \mathrm{~m}$ ) (Qu et al. 2006; Shao et al. 2007; Zhao et al. 2014). It is noteworthy that the depths of the interfaces between these currents vary spatiotemporally (Luan et al. 2012; Wang et al. 2018a), which can significantly change the sediment distributions. On the other hand, downslope gravity flows play an important role around the Pearl River Canyon (Fig. 1) (Wang et al. 2018a), where turbidite channels and gullies are possible conduits (Sun et al. 2016). In addition, the surface Guangdong Coastal Current (GCC) and South China Sea Warm Current (SCSWC) (Fig. 1) can influence the sediment distribution on the shelf (Cao et al. 2019).

\section{Materials and methods}

\subsection{Materials and chronological framework}

Four sites on the northern SCS slope with different water depths $(585-2125 \mathrm{~m})$ are utilized in this study. Marine sediment cores from sites DLW3101 (20 09.90' $\mathrm{N}, \quad 115^{\circ} 21.30^{\prime} \mathrm{E}$, water depth $\left.585 \mathrm{~m}\right), \quad$ MD12-3429 $\left(20^{\circ} 08.52^{\prime} \mathrm{N}, 115^{\circ} 49.84^{\prime} \mathrm{E}\right.$, water depth $\left.903 \mathrm{~m}\right)$ and MD12-3432 $\left(19^{\circ} 16.88^{\prime} \mathrm{N}, 116^{\circ} 14.52^{\prime} \mathrm{E}\right.$, water depth 2125 $\mathrm{m})$ were all collected on the continental slope of the northern SCS (Fig. 1). Site DLW3101 was cored in 2014 by Offshore Oil 708 (Zhou et al. 2018), and sites MD123429 and MD12-3432 were cored in 2012 by R.V. Marion Dufresne (Kissel et al. 2012). The sediments at these sites are homogenous and predominantly gray silts and clays (Kissel et al. 2012; Li et al. 2017; Zhou et al. 2018), and no obvious hiatus is found. A total of 122 samples were taken continuously at around $35 \mathrm{~cm}$ intervals from the upper $42.555 \mathrm{~m}$ of Core DLW3101 for element composition analysis, and 9 samples were taken from $30.490-40.010 \mathrm{~m}$ for mineral content analysis. Fifty samples were taken continuously at around $20 \mathrm{~cm}$ intervals from $10.055-19.855 \mathrm{~m}$ of site MD12-3429, and 100 samples were taken continuously at around $20 \mathrm{~cm}$ intervals from upper $18.405 \mathrm{~m}$ of Core MD12-3432 for element composition analysis. Besides, the elemental and mineral data of site ZHS- $176\left(20^{\circ} 00.07^{\prime} \mathrm{N}, 115^{\circ} 33.35^{\prime} \mathrm{E}\right.$, water depth $1383 \mathrm{~m}$ ) are derived from Zhang et al. (2013) and Ge et al. (2010).

We reconstruct the age models of DLW3101 and MD12-3429 based on planktonic foraminiferal $\delta^{18} \mathrm{O}$ stratigraphy ( $\mathrm{Li}$ et al. 2017; Zhou et al. 2018), and the age points of sites ZHS-176 (Ge et al. 2010; Zhang et al. 2013) and MD12-3432 (Chen et al. 2017b; Wang et al. 2018b) are also presented (Fig. 2a). The linear sedimentation rates (LSRs) of sites DLW3101, MD12-3429 and MD12-3432 are all higher during glacial periods (Fig. $2 \mathrm{~b})$, whereas the LSR of ZHS-176 is higher during the Holocene, and the average LSRs of sites DLW3101, MD12-3429, ZHS-176, MD12-3432 are approximately $33.55,14.42,24.44$ and $14.44 \mathrm{~cm} / \mathrm{ka}$, respectively.

\subsection{Analytical methods}

Detrital silicates in sediments were extracted following a sequential leaching procedure, and the major elements were measured on a Spectro Blue Sop inductively coupled plasma-optical emission (ICP-OES) at Peking University. The extraction procedure included five steps (Gonneea and Paytan 2006; Zhao et al. 2018). First, the water-soluble fractions were removed by rinsing with ultrapure water (Leleyter et al. 2012). Second, a $\mathrm{CH}_{3} \mathrm{COONH} \mathrm{H}_{4} / \mathrm{CH}_{3} \mathrm{COOH}$ buffer solution at $\mathrm{pH} 4.5$ was added to remove carbonates at $60^{\circ} \mathrm{C}$ for $48 \mathrm{~h}$. Third, the organic matter was removed by $10 \% \mathrm{H}_{2} \mathrm{O}_{2}$ at $60^{\circ} \mathrm{C}$ for 1 h. Forth, the silicate residues were dissolved using a concentrated $\mathrm{HF}+\mathrm{HNO}_{3}+\mathrm{HCl}$ mixture on a hot plate at $150{ }^{\circ} \mathrm{C}$ for $24 \mathrm{~h}$. Finally, samples were diluted with $2 \%$ $\mathrm{HNO}_{3}$ for major element measurement. The external reproducibility for the elements $(\mathrm{Na}, \mathrm{Mg}, \mathrm{Al}, \mathrm{K}, \mathrm{Ca}, \mathrm{P}$, and Ti) in silicate residues was $\pm 5 \%$.

Mineralogical compositions of bulk sediments were measured by X-ray diffraction (XRD). First, noncalcareous clay-sized $(<2 \mu \mathrm{m})$ particles were separated following pretreatment steps of air-drying, ethyleneglycol solvation for $24 \mathrm{~h}$, and heating at $490^{\circ} \mathrm{C}$ for $2 \mathrm{~h}$ (Liu et al. 2016). Clay minerals were identified according to the position of the (001) series of basal reflections on the three XRD diagrams, and the experiments were performed at the State Key Laboratory of Marine Geology, Tongji University. Replicate analyses of selected samples gave a precision of $\pm 2 \%(2 \sigma)$, and the semiquantitative evaluation of each clay mineral had an accuracy of $\sim 5 \%$.

\section{Results}

\subsection{Major element compositions}

Major element compositions at sites DLW3101, MD123429 and MD12-3432 vary on glacial-interglacial cycles. 


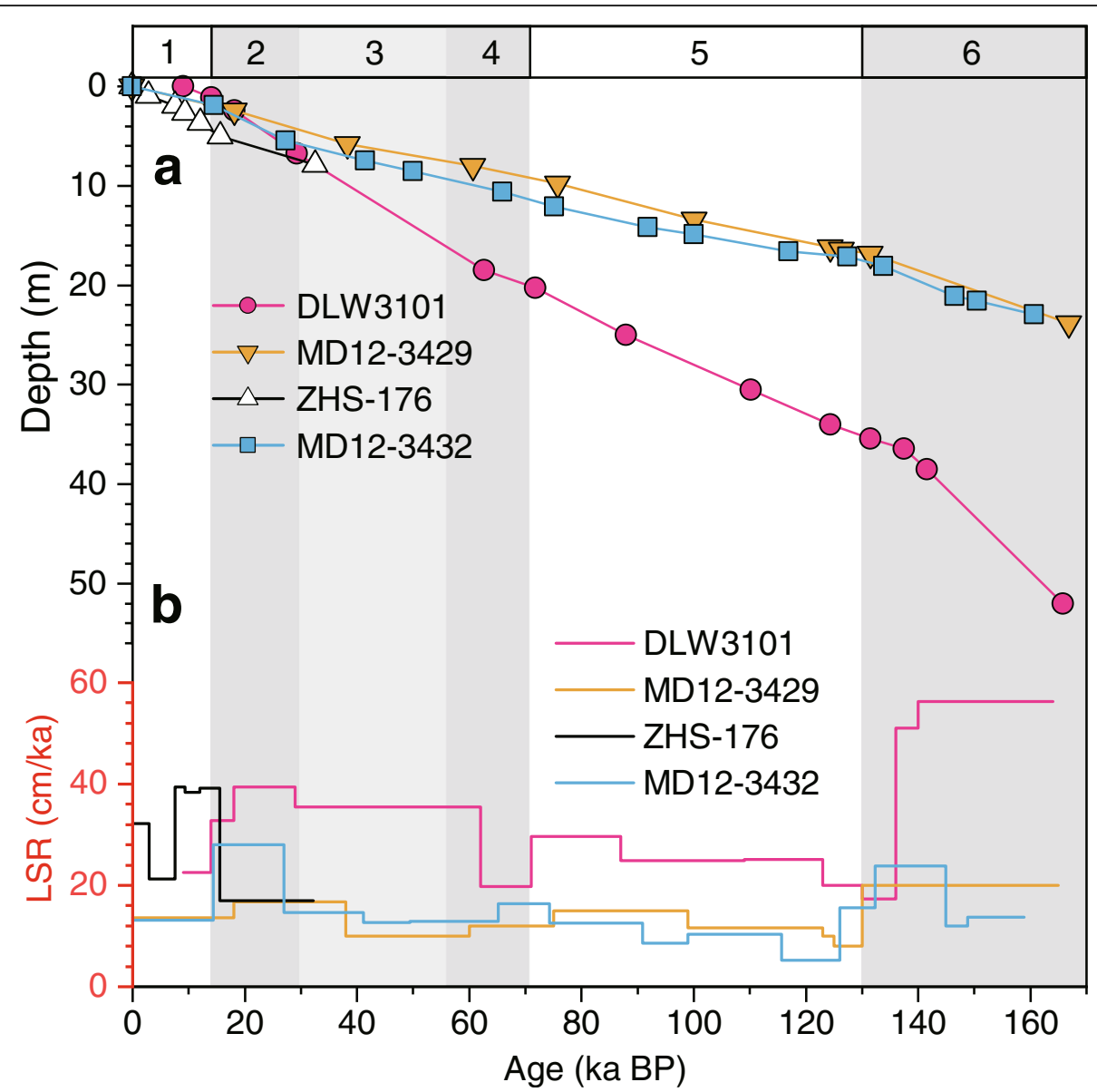

Fig. 2 Age model of the study sites DWL3101, MD12-3429, ZHS-176 and MD12-3432. a Age models of sites DLW3101 and MD12-3429 based on the planktic $\delta^{18} \mathrm{O}$ data from Zhou et al. (2018) and Li et al. (2017); the age model of ZHS-176 is from Ge et al. 2010 and Zhang et al. 2013; and the age model of MD12-3432 is from Chen et al. (2017b) and Wang et al. (2018a); b Linear sedimentation rates (LSRs) of DLW3101, MD12-3429, ZHS-176 and MD12-3432. Gray bars highlight glacial periods with marine isotope stages (MIS) noted on the top

At DLW3101, the concentrations of $\mathrm{Al}_{2} \mathrm{O}_{3}, \mathrm{~K}_{2} \mathrm{O}, \mathrm{P}_{2} \mathrm{O}_{5}$, $\mathrm{MgO}$ and $\mathrm{TiO}_{2}$ are higher during marine isotope stage (MIS) 1 and 5 and lower during MIS 2-4 and MIS 6, whereas $\mathrm{Na}_{2} \mathrm{O}$ and $\mathrm{CaO}$ behave oppositely (Fig. 3). At MD12-3429, the concentrations of $\mathrm{Al}_{2} \mathrm{O}_{3}, \mathrm{~K}_{2} \mathrm{O}, \mathrm{P}_{2} \mathrm{O}_{5}$, $\mathrm{MgO}$ and $\mathrm{TiO}_{2}$ are higher during interglacials and lower during glacials. The concentrations of $\mathrm{Na}_{2} \mathrm{O}$ are higher in MIS 6 and lower in MIS 5, while $\mathrm{CaO}$ does not change significantly from $150 \mathrm{ka}$ to $75 \mathrm{ka}$ (Fig. 3). At MD12-3432, the changes in $\mathrm{K}_{2} \mathrm{O}, \mathrm{P}_{2} \mathrm{O}_{5}, \mathrm{MgO}$ and $\mathrm{TiO}_{2}$ are similar to those in DLW3101, but $\mathrm{Al}_{2} \mathrm{O}_{3}$ is almost constant during $100-15 \mathrm{ka} . \mathrm{Na}_{2} \mathrm{O}$ and $\mathrm{CaO}$ are also similar to those in DLW3101 except for the much higher values during 30-22 ka (Fig. 3).

\subsection{Clay mineral compositions}

The assemblage of clay minerals in DLW3101 mainly consists of smectite $(31 \%-51 \%)$ and illite $(23 \%-38 \%)$ with minor chlorite $(15 \%-22 \%)$ and kaolinite $(6 \%-17 \%)$ (Fig. 4). Apart from the deglacial period, the most significant changes in mineral content during 145$110 \mathrm{ka}$ are the increases in illite and chlorite, whereas the kaolinite percentage decreases. The illite crystallinity shows a higher value of 0.18 during $145-140 \mathrm{ka}$ and a lower value of 0.15 during $125-110 \mathrm{ka}$, suggesting the occurrence of relatively unaltered illites during MIS 5. The illite chemical index is also higher during MIS 6. In addition, the smectite/(illite + chlorite) ratio decreases from 0.9 during MIS 6 to 0.7 during MIS 5, while the kaolinite/(illite + chlorite) ratio reveals a more significant decreasing trend from 0.4 to 0.2 during $145-110 \mathrm{ka}$ (Fig. 4).

\section{Discussion}

\subsection{Proxies of sediment provenance}

The sediment provenance proxies we proposed here are $R_{A K}$ and $R_{K C N}$, which are derived by the chemical index of alteration (CIA) based on major element contents. The CIA is defined as $\mathrm{Al}_{2} \mathrm{O}_{3} /\left(\mathrm{Al}_{2} \mathrm{O}_{3}+\mathrm{CaO} "+\mathrm{Na}_{2} \mathrm{O}+\right.$ $\left.\mathrm{K}_{2} \mathrm{O}\right) \times 100$ by using molar percentages of the major 


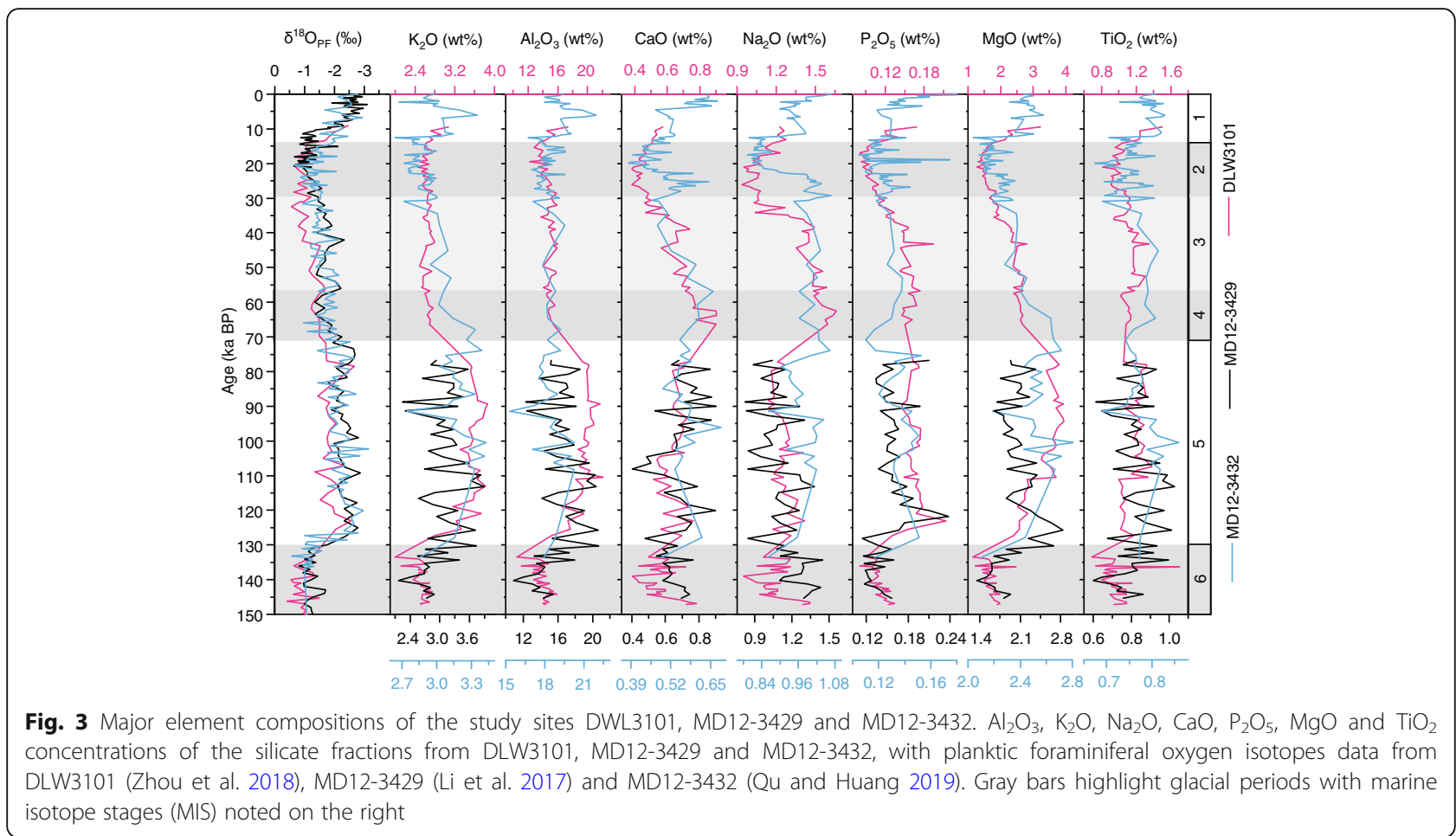

element oxides, where $\mathrm{CaO}^{\prime \prime}$ represents the $\mathrm{CaO}$ in the silicate fraction (Nesbitt and Young 1982). In general, the chemical leaching conditions of mobile alkali and alkaline elements can be visualized using weathering trend plots, such as the $\mathrm{Al}_{2} \mathrm{O}_{3}-\left(\mathrm{CaO}^{*}+\mathrm{Na}_{2} \mathrm{O}\right)-\mathrm{K}_{2} \mathrm{O}(\mathrm{A}-\mathrm{CN}-\mathrm{K})$ ternary diagram (Fig. 5) (Nesbitt and Young 1984, 1989; Fedo et al. 1995). Sediments on the northern SCS slope are mainly sourced from the Pearl River, Taiwan and Luzon at the modern time (Liu et al. 2017), so we plot the terrestrial samples $(<63 \mu \mathrm{m})$ (Liu et al. 2016) from these three regions on the A-CN-K diagram (Fig. 5). It is noteworthy that not only the weathering intensities are not overlapped, but also the weathering trends are distinct for the three regions (Fig. 5).
Theoretically, the weathering trends can be divided into two steps due to the prior removal of $\mathrm{Na}_{2} \mathrm{O}$ and $\mathrm{CaO}$ relative to $\mathrm{K}_{2} \mathrm{O}$ (Nesbitt and Young 1984, 1989; Fedo et al. 1995), and these two steps of weathering can be observed in the samples from the three major sources (Fig. 5). Taiwan samples plot almost perpendicular to the $\mathrm{A}-\mathrm{K}$ line (Fig. 5), which means that the leaching of $\mathrm{CaO}$ and $\mathrm{Na}_{2} \mathrm{O}$ is preferential while $\mathrm{K}_{2} \mathrm{O}$ is still fixed in the weathering products (e.g., illite) (Liu et al. 2016). Ultimately, the absence of intermediate-acid rocks and extremely strong physical erosion are the primary factors that prevent the leaching of $\mathrm{K}_{2} \mathrm{O}$ (Liu et al. 2016). In contrast, the Pearl River samples plot linearly and are

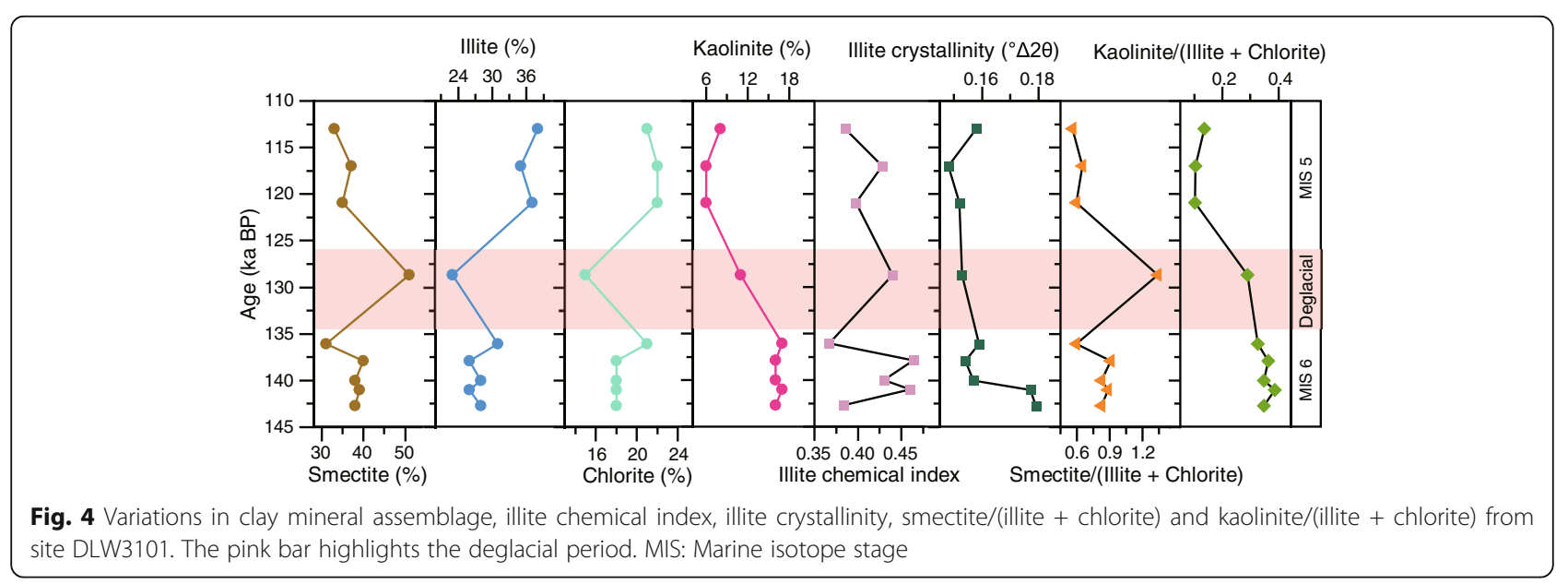



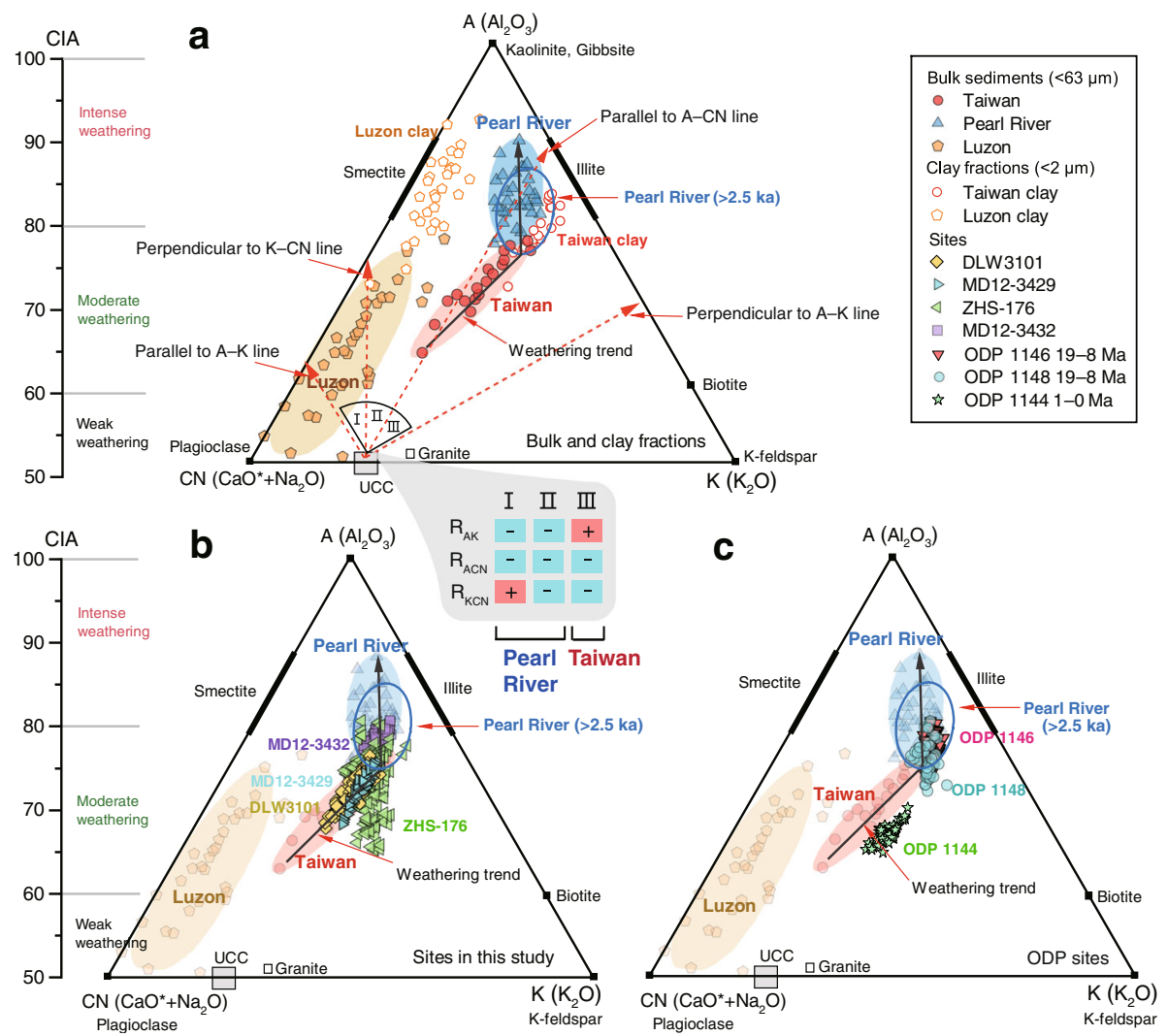

Fig. 5 Variations of the weathering trends of the source regions and the calculations of $R_{A K}, R_{A C N}$ and $R_{K C N}$. Major elemental $\mathrm{Al}_{2} \mathrm{O}_{3}-\left(C_{C a O}{ }^{*}+\right.$ $\left.\mathrm{Na}_{2} \mathrm{O}\right)-\mathrm{K}_{2} \mathrm{O}(\mathrm{A}-\mathrm{CN}-\mathrm{K})$ diagram of bulk and clay-fraction sediments in a surrounding fluvial drainage systems (modified from Liu et al. 2016), $\mathbf{b}$ sites DLW3101, MD12-3429, ZHS-176, MD12-3432, as well as c ODP sites 1144 (Wei et al. 2003), 1146 (Wan et al. 2010b) and 1148 (Wei et al. 2006). $\mathrm{CaO}^{*}$ represents the $\mathrm{CaO}$ in the silicate fraction (Nesbitt and Young 1982). The three sectors (I, II and III) in (a) represent the ranges of weathering trends. And the diagram presents the calculated positive and negative values of $R_{A K}, R_{A C N}$ and $R_{K C N}$ in the three regions. $R_{A K}, R_{A C N}$ and $R_{K C N}$ are the correlation coefficients between the chemical index of alteration $(\mathrm{CIA}), \mathrm{K}^{*}$ and $\mathrm{CN}^{*}$. $\mathrm{CIA}=\mathrm{Al}_{2} \mathrm{O}_{3} /\left(\mathrm{Al}_{2} \mathrm{O}_{3}+\mathrm{CaO}^{*}+\mathrm{Na}_{2} \mathrm{O}+\mathrm{K}_{2} \mathrm{O}\right) \times 100 ; \mathrm{K}^{*}=\mathrm{K}_{2} \mathrm{O}$ / $\left(\mathrm{Al}_{2} \mathrm{O}_{3}+\mathrm{CaO}^{*}+\mathrm{Na}_{2} \mathrm{O}+\mathrm{K}_{2} \mathrm{O}\right) \times 100 ; \mathrm{CN}^{*}=\left(\mathrm{CaO}^{*}+\mathrm{Na}_{2} \mathrm{O}\right) /\left(\mathrm{Al}_{2} \mathrm{O}_{3}+\mathrm{CaO}^{*}+\mathrm{Na}_{2} \mathrm{O}+\mathrm{K}_{2} \mathrm{O}\right) \times 100$. RAK: Pearson's $r$ between ClA and $\mathrm{K}^{*} ; \mathrm{R}_{\mathrm{ACN}}:$ Pearson's $r$ between $\mathrm{CIA}$ and $\mathrm{CN}^{*}$; $\mathrm{R}_{\mathrm{KCN}}$ : Pearson's $r$ between $\mathrm{K}^{*}$ and $\mathrm{CN}^{*}$. The range of Pearl River samples ( $2.5 \mathrm{ka}$ ) is estimated based on Hu et al. (2016). The black polylines show the weathering trends. UCC: Upper continental crust

nearly perpendicular to the $\mathrm{K}-\mathrm{CN}$ line (Fig. 5), associating with the abundant kaolinite contents in the modern Pearl River basin and the Holocene estuary sediments (Hu et al. 2013; Liu et al. 2016). These pieces of evidence all suggest that the leaching of $\mathrm{CaO}$ and $\mathrm{Na}_{2} \mathrm{O}$ and the removal of $\mathrm{K}_{2} \mathrm{O}$ are simultaneously occurring in the sediments around the drainage basin. Luzon river samples plot linearly and parallel to the $\mathrm{A}-\mathrm{CN}$ line (Fig. 5), indicating preferential leaching of $\mathrm{CaO}$ and $\mathrm{Na}_{2} \mathrm{O}$ as well as lacking $\mathrm{K}_{2} \mathrm{O}$ in the bedrocks (Liu et al. 2009).

Since the obvious differences exist in weathering trends between the Pearl River, Taiwan and Luzon islands, we can use these features to indicate provenance change once the weathering trend can be presented numerically. The weathering trends can be analyzed by correlation coefficients between CIA, $\mathrm{K}^{* \prime}$ and $\mathrm{CN}^{\prime \prime}\left(\mathrm{K}^{\prime \prime}=\right.$ $\mathrm{K}_{2} \mathrm{O} /\left(\mathrm{Al}_{2} \mathrm{O}_{3}+\mathrm{CaO}^{\prime \prime}+\mathrm{Na}_{2} \mathrm{O}+\mathrm{K}_{2} \mathrm{O}\right) \times 100 ; \mathrm{CN}^{\prime \prime}=\left(\mathrm{CaO}^{\prime \prime}+\right.$ $\left.\left.\mathrm{Na}_{2} \mathrm{O}\right) /\left(\mathrm{Al}_{2} \mathrm{O}_{3}+\mathrm{CaO}^{*}+\mathrm{Na}_{2} \mathrm{O}+\mathrm{K}_{2} \mathrm{O}\right) \times 100\right)$. The three sectors (Fig. 5a) represent the direction ranges of possible weathering trends. And the diagram presents the calculated positive and negative regions values of $R_{A K}$, $R_{A C N}$ and $R_{K C N}$ in the three regions $\left(R_{A K}\right.$ : Pearson's $r$ between CIA and $K^{*} ; R_{A C N}$ : Pearson's $r$ between CIA and $\mathrm{CN}^{*} ; \mathrm{R}_{\mathrm{KCN}}$ : Pearson's $\mathrm{r}$ between $\mathrm{K}^{*}$ and $\left.\mathrm{CN}^{*}\right)$. The $R_{A C N}$ values are negative all along, so it is useless for provenance tracking. The weathering trend of modern Taiwan locates in the sector I range, and the trend of modern Pearl River samples lies at the border between the sector II and III. The positive $\mathrm{R}_{\mathrm{AK}}$ only appears in sector III, while the positive $R_{K C N}$ can be worked out only in sector I (Fig. 5a). The value of $R_{A K}$ becomes more negative when $\mathrm{K}$-feldspar breakdown proceeds rapidly, which means the leaching of $\mathrm{K}_{2} \mathrm{O}$, while more positive $\mathrm{R}_{\mathrm{KCN}}$ values also signal more intense $\mathrm{K}$-feldspar destruction (Fig. 5). We calculate these correlation coefficients of the surface sediments samples from the Pearl 

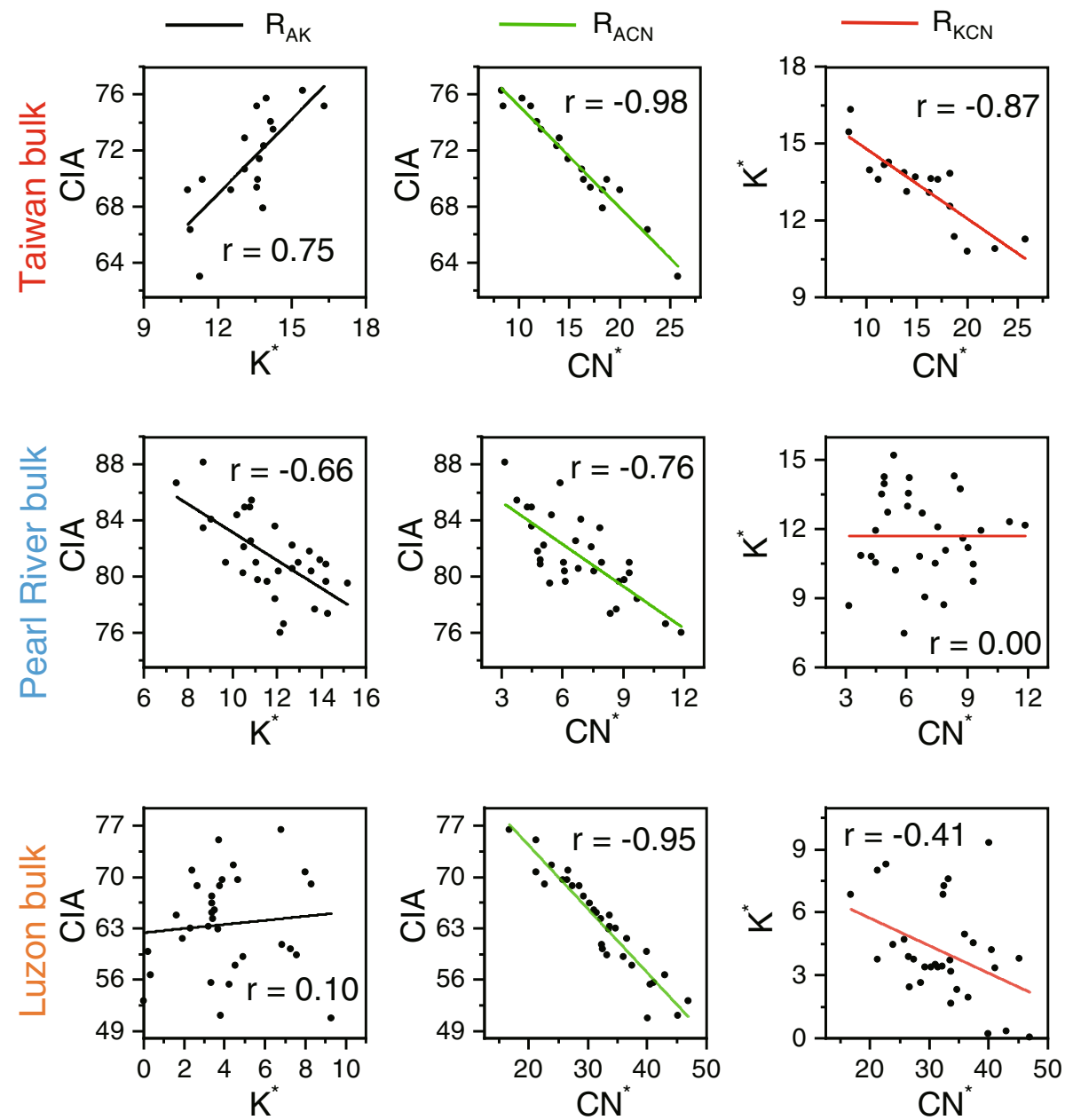

Fig. 6 The $R_{A K}, R_{A C N}$ and $R_{K C N}$ values of bulk sediments from Taiwan, the Pearl River and Luzon. $p$-values are all $<<0.01$ when $|r|>0.5$ (here, $p$-value $\leq 0.05$ is statistically significant, which means the correlation exists with high probability). See Fig. 5 for meanings of $C I A, K^{*}, C N^{*}, R_{A K}, R_{K C N}$ and $R_{K C N}$

River, Taiwan and Luzon (Fig. 6) (Liu et al. 2016). It is noteworthy that the three potential sources show significant differences in $\mathrm{R}_{\mathrm{AK}}$ and $\mathrm{R}_{\mathrm{KCN}}$ values (Fig. 6). Because the Luzon input is low in our study area (Liu et al. 2011; Zhong et al. 2017) and the $\mathrm{R}_{\mathrm{AK}}, \mathrm{R}_{\mathrm{ACN}}$ and $\mathrm{R}_{\mathrm{KCN}}$ values between Luzon and Taiwan are relatively similar, we focus on the sediments that supply from the Pearl River and Taiwan. The $R_{A K}$ values of the Pearl River are strongly negative, whereas the $R_{A K}$ of Taiwan is strongly positive. The $R_{K C N}$ of the Pearl River is not significantly different from zero, while the $R_{K C N}$ of Taiwan is negative. As there is little difference in the $R_{A C N}$ values between the Pearl River and Taiwan sources (Fig. 6), we consider the $R_{A K}$ and $R_{K C N}$ values to be more effective for revealing the provenance changes the history of the northern SCS.

Furthermore, we calculate the $R_{A K}$ and $R_{K C N}$ values of three ODP sites (Figs. 5c, 7). The results suggest that the sediments at ODP site 1144 (1-0 Ma) are mainly sourced from Taiwan, while those at ODP sites 1146 (19-8 Ma) and 1148 (19-8 Ma) are mainly sourced from the Pearl River (Fig. 7b). The conclusions draw by $\mathrm{R}_{\mathrm{AK}}$ and $\mathrm{R}_{\mathrm{KCN}}$ values are exactly matched with those previous results declared by clay mineral data (Fig. 7a) (Wan et al. 2010a), and the conclusions derived from sedimentary lithofacies and trace elements (Wei et al. 2012; Shao et al. 2019; Zhang et al. 2020) also support our results. Besides, the $\mathrm{Sr}-\mathrm{Nd}$ isotope data also indicate the same condition (Fig. 7c) (Chen and Lee 1990; Clift et al. 2002, 2014; Lan et al. 2002; Zhou et al. 2002; Liu et al. 2007; $\mathrm{Hu}$ et al. 2012, 2013). However, the $\varepsilon_{\mathrm{Nd}}$ values of Taiwan and the Pearl River are so similar, while the ${ }^{87} \mathrm{Sr} /{ }^{86} \mathrm{Sr}$ values are primarily controlled by chemical weathering (Fig. 7c) (Hu et al. 2012; Clift et al. 2014), and the influence of Taiwan after $5 \mathrm{Ma}$ makes a simple weathering interpretation of the $\mathrm{Sr}$ isotope data impossible (Clift et al. 2014). Therefore, the application of $\mathrm{Sr}-\mathrm{Nd}$ isotope in the northern SCS needs to be more cautious especially after Taiwan uplift. 
In addition, the $p$-values are $<0.05$ just when $|\mathrm{r}|>0.6$, which means that the source indicative significance of $R_{A K}$ or $\mathrm{R}_{\mathrm{KCN}}$ is meaningful only under these conditions. Nevertheless, we cannot regard the $\mathrm{r}$ value as totally meaningless if $p$-values are $>0.05$, when it is also a signal indicating a mixture of Taiwan and Pear River sediments. Fortunately, the $p$-values are always $<0.05$ during most periods at the four study sites and ODP sites we referred to (Fig. 7b, 8). In summary, the $R_{A K}$ and $R_{K C N}$ we encouraged in this study are robust provenance proxies in the northern SCS.

\subsection{Spatiotemporal patterns of sediment deposition}

We try to discuss the temporal variations in sediment provenance on the northern SCS slope based on the provenance proxies $R_{A K}$ and $R_{K C N}$. The values of $R_{A K}$ and $R_{K C N}$ are calculated for every continuous 10 points of the data from sites DLW3101, MD12-3429 and MD12-3432. The sample quantities of site ZHS-176 is tenfold than other three sites per unit time, to guarantee a similar time interval during every calculation, we pick 30 points from site ZHS-176 for each compute. The upper continental slope is represented by sites DLW3101 and MD12-3429, while sites ZHS-176 and MD12-3432 represent the middle and lower slopes, respectively. In addition, we put forward the kaolinite/(illite + chlorite) ratio as an additional proxy for source identification, as kaolinite is mostly provided by the Pearl River, and illite and chlorite are mainly from Taiwan (Liu et al. 2016). Nevertheless, the contribution of the Pearl River since $2.5 \mathrm{ka}$ can be overestimated because of the influence of anthropological activity (Hu et al. 2013).

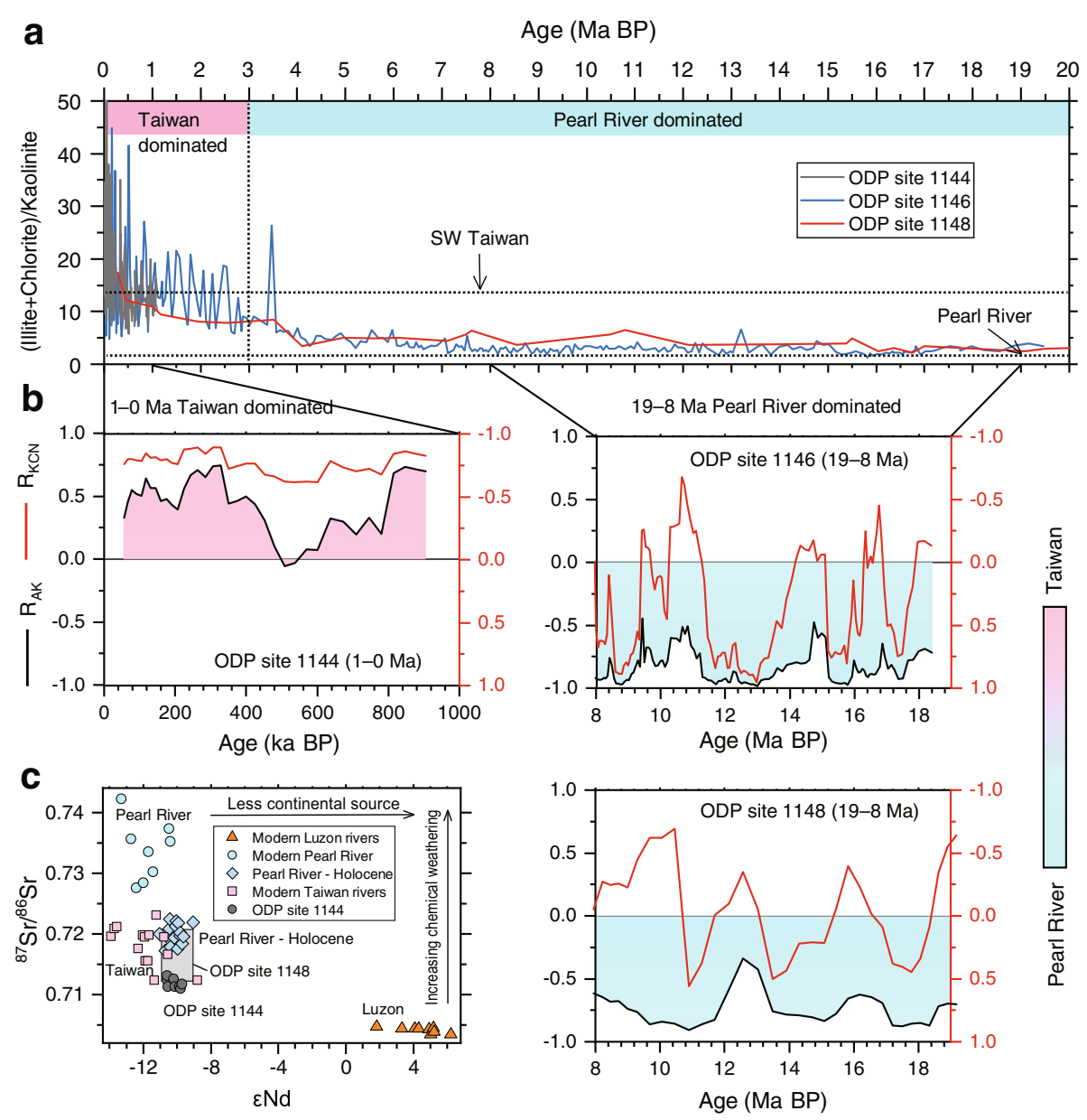

Fig. 7 The correlation between the new proxies $R_{A K}, R_{K C N}$ and other provenance indictors. a Variation of (illite + chlorite)/kaolinite ratio (modified from Wan et al. 2010a) at ODP sites 1144 (Wan et al. 2010a), 1146 (Wan et al. 2007), and 1148 (Clift et al. 2002); b Changes in $R_{A K}$ and $R_{K C N}$ values of ODP sites 1144 (1-0 Ma), 1146 (19-8 Ma) and 1148 (19-8 Ma); $p$-values are almost all < 0.05 when $|r|>0.6$; c $\mathrm{Sr}$ and Nd isotopic plot showing the variability in Holocene sediments from ODP site 1144 (Hu et al. 2012) and in Lower Miocene to recent sediments at ODP site 1148 (Clift et al. 2002, 2014) compared to modern potential sources (Chen and Lee 1990; Lan et al. 2002; Zhou et al. 2002; Liu et al. 2007; Hu et al. 2013) around the South China Sea (modified from Clift et al. 2014). The fill colors of the $R_{A K}$ line mark the relative distribution of Taiwan (red) and the Pearl River (blue). See Fig. 5 for meanings of $R_{A K}$ and $R_{K C N}$ 


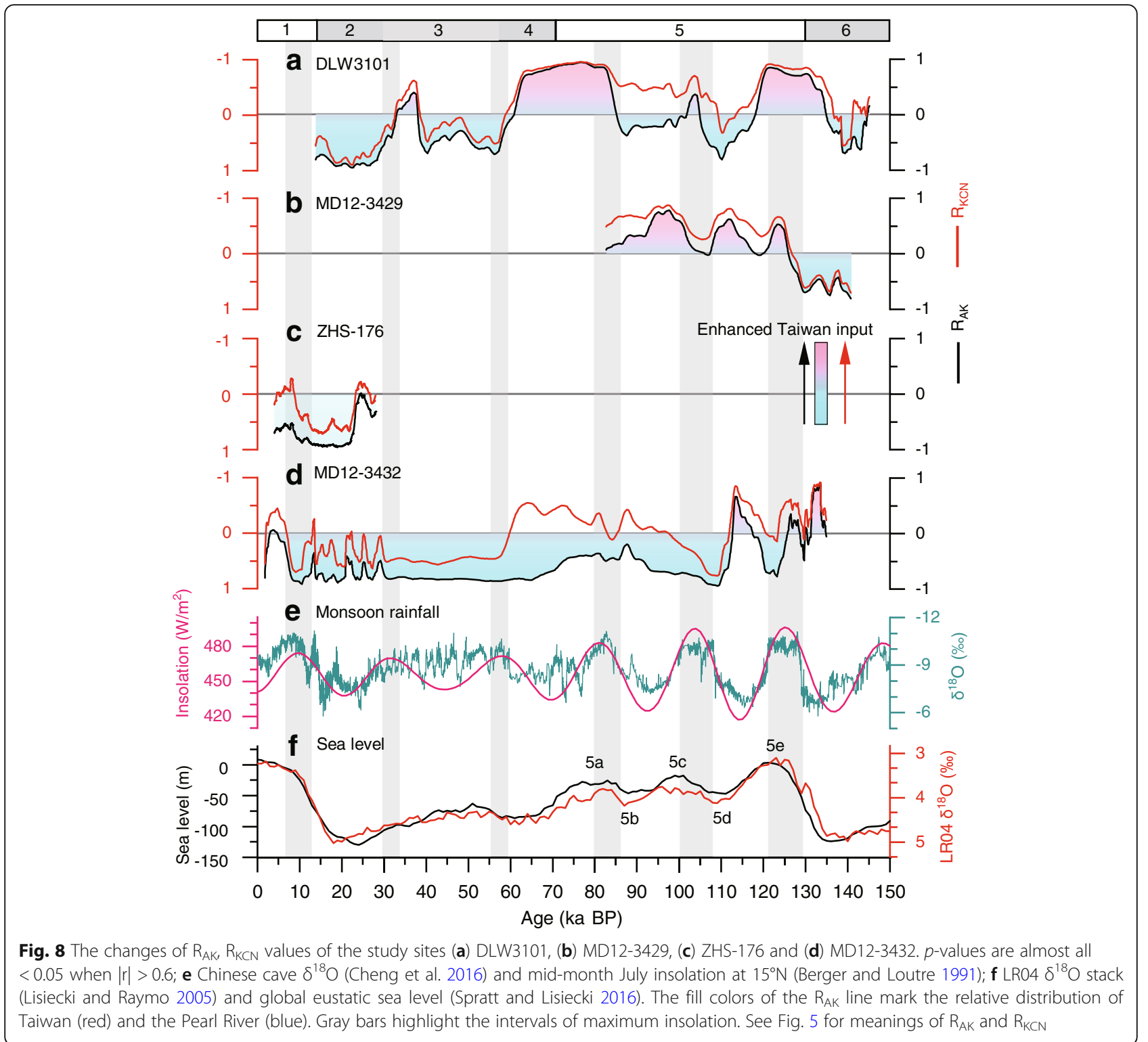

The two sites DLW3101 and MD12-3429 on the upper slope show similar changes in the $\mathrm{R}_{\mathrm{AK}}$ values, which are more positive when the sea level is higher (Fig. 8a, b). During $127-115 \mathrm{ka}$, the positive $\mathrm{R}_{\mathrm{AK}}$ values at DLW3101 indicate higher sediment input from Taiwan, consistent with the lower kaolinite/(illite + chlorite) ratios and higher illite crystallinity values (Fig. 4), which are also signals of greater Taiwan input (Liu et al. 2016). During $145-135 \mathrm{ka}$ and $25-18 \mathrm{ka}$, the strong negative $R_{A K}$ values suggest increases of the Pearl River input. Moreover, the CIA values are relatively high with the finer mean grain size of DLW3101 during interglacial periods, but the CIA values are even higher during glacial maxima with larger grain sizes (Fig. 9d). In addition, it is strange that the highest positive $\mathrm{R}_{\mathrm{AK}}$ occurred at early
MIS 4, and we take the most possible reason is the lacking of samples during 77-67 ka at DLW3101.

At MD12-3429, the positive $R_{A K}$ values are present at approximately $130-82 \mathrm{ka}$ together with the negative $\mathrm{R}_{\mathrm{KCN}}$ (Fig. 8b), indicating a higher Taiwan sediment input during the high sea level stage. The $\mathrm{R}_{\mathrm{AK}}$ values are negative during $145-130 \mathrm{ka}$, which represents a relatively higher sediment input from the Pearl River. In general, the upper slope receives more Taiwan sediment during high sea level stages and less in lowstands.

On the middle slope, given the strong negative values of $R_{A K}$, there is no significant Taiwan sediment input over the last $30 \mathrm{ka}$ at ZHS-176 (Fig. 8c). The illite crystallization values are always much higher 


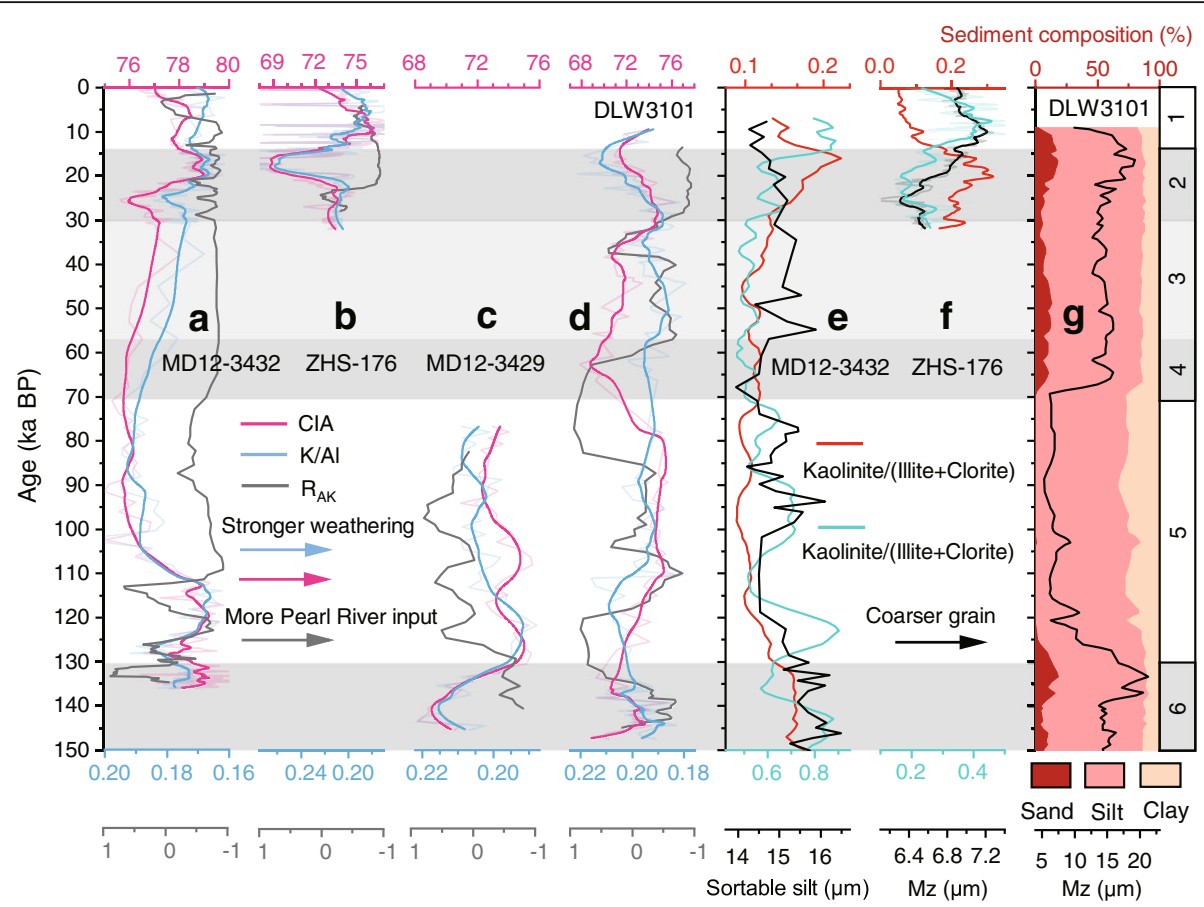

Fig. 9 The changes of material composition, grain size and chemical weathering proxies. The values of KVAl and CIA of the silicate fractions from (a) MD12-3432, (b) ZHS-176, (c) MD12-3429, and (d) DLW3101. The semi-transparent lines represent the original data, and the bold lines are 10point running averages in (a), (c) and (d) and 50-point running averages in (b) and (f). The mean grain size (Mz) and clay mineral assemblage variations from (e) MD12-3432 (Chen et al. 2017a, b) and (f) ZHS-176 (Ge et al. 2010; Zhang et al. 2013). g The mean grain size (Mz) and sediment compositions in DLW3101 (modified from Zhou et al. 2018). See Fig. 5 for the meaning of CIA

than the Taiwan range (Ge et al. 2010), also suggesting a higher input from the Pearl River. Further, the kaolinite/(illite + chlorite) ratios (Fig. 9f) indicate that the Pearl River input is relatively higher during the low sea level stage.

On the lower slope, the $R_{A K}$ values at MD12-3432 are always negative during 110-10 ka (Fig. 8d), and the kaolinite percentages and CIA values are higher during glacial periods (Fig. 9a, e) (Chen et al. 2017a). These all suggest a higher sediment contribution from the Pearl River during 110-10 ka, even higher in glacials. By contrast, the $R_{A K}$ values reach a moderate positive level during 135-110 ka (Fig. 8d), indicating higher Taiwan sediment input during the high sea level stage.

\subsection{Influencing factors on $\mathrm{R}_{\mathrm{AK}}$ and $\mathrm{R}_{\mathrm{KCN}}$}

Besides provenance change, there are still other factors can affect the values of $R_{A K}$ and $R_{K C N}$ such as hydraulic sorting and chemical weathering. However, the influences of these two factors on the new provenance proxies are weak in the northern SCS.

As for hydraulic sorting, in the source areas, the weathering trends of clay fractions $(<2 \mu \mathrm{m})$ of Taiwan and Luzon sediments do not show significant differences from bulk sediments $(<63 \mu \mathrm{m})$ (Fig. 5), indicating that the influences of hydraulic sorting on the weathering trends of the sediments from Taiwan and Luzon are negligible. For the sink regions, the weathering intensity inferred from the CIA and $\mathrm{K} / \mathrm{Al}$ ratio is extremely high during MIS 2 and MIS 6 at DLW3101 with the largest grain sizes (Fig. 9d, g). The larger grain sizes are also coincident with more intense weathering at ZHS-176 since $14 \mathrm{ka}$ (Ge et al. 2010; Zhang et al. 2013) (Fig. 9b, f). At MD12-3432, the higher mean grain size of the sortable silt is not always appearing at the same time with lower $\mathrm{CIA}$ or $\mathrm{K} / \mathrm{Al}$ values (Fig. 9a). In total, the weathering intensity always rises with a larger grain size in these four sites. However, larger grain size should indicate weaker weathering (Xiong et al. 2010; Huang et al. 2011; Israeli and Emmanuel 2018; Hatano et al. 2019), because the more presence of quartz leads to the loss of weathering sensitive minerals, and the silt fraction may contain abundant micas which have lower CIA values than clays (Andrews et al. 2003). In other words, the grain size effect on weathering is not always conformed to the theory.

In the northern SCS, the only way that hydraulic sorting can influence the judgment by $\mathrm{R}_{\mathrm{AK}}$ and $\mathrm{R}_{\mathrm{KCN}}$ is winnowing fine-grained particles from the Pearl River, getting the weathering intensity down, finally pushing the weathering trends to Taiwan-type. Nevertheless, 
these procedures never happen as the weathering trends are always showing a $\mathrm{K}_{2} \mathrm{O}$ leaching type when grain size becomes larger. Thus, hydraulic sorting has little influence on the proxies $R_{A K}$ and $R_{K C N}$ at these four sites during the most time since $150 \mathrm{ka}$.

As for chemical weathering, firstly, the temporal variations of provenance proxies and weathering proxies are different in most cases (Fig. 9). That is because $R_{A K}$ and $R_{K C N}$ reflect the direction of weathering trend, while $\mathrm{CIA}$ and $\mathrm{K} / \mathrm{Al}$ show the weathering intensity of the mixture sediment on the slope. Secondly, the periodicities of $\mathrm{R}_{\mathrm{AK}}$ and $\mathrm{K} / \mathrm{Al}$ are more distinct than CIA (Fig. 10), because the weathering intensity of the mixture is influenced by weathering condition, hydraulic sorting and provenance change simultaneously, while the climaterelated periodicities of these factors are asynchronous. On the other hand, the provenance change is mainly controlled by the climate in the northern SCS, especially sea level and rainfall, these will be discussed at length in the next section. Besides, potassium enriches in illite, which is the major component of Taiwan clay, so the K/ $\mathrm{Al}$ ratio rather than the CIA is strongly influenced by provenance change.

Otherwise, the weathering conditions of Taiwan and the Pearl River did not become significantly different during the LGP (Liu et al. 2016; Wan et al. 2017, 2020). During glacial lowstands, the unconsolidated shelf sediments near the Paleo-Pearl River are transported to the slope, where they would be subject to an even greater degree of weathering (Wan et al. 2017). And this would not change the weathering trend direction of the Pearl River region. For Taiwan, the chemical weathering is stable since the LGM, as it is limited by the extremely high physical erosion (Selvaraj and Chen 2006; Liu et al. 2016; Wan et al. 2020). The constant clay contents of the sites around Taiwan indicate the element compositions are unaltered. The weathering trend of Taiwan is suggested to be constant over the last $150 \mathrm{ka}$. Therefore, the modern surface samples we use from the Pearl River and Taiwan are suitable to represent the condition since $150 \mathrm{ka}$.

In general, hydraulic sorting and chemical weathering can influence the sediment composition, but these factors cannot change the weathering trends of sediments from Taiwan or the Pearl River thoroughly, so that the provenance proxies $R_{A K}$ and $R_{K C N}$ are independent of both hydraulic sorting and chemical weathering. After ruling out the impacts of chemical weathering in the source regions and hydraulic sorting during transport, we suggest that the provenance change can be revealed by $R_{A K}$ and $R_{K C N}$ more credibly in this study area since $150 \mathrm{ka}$.

\subsection{Controlling mechanisms of sediment transport}

As to the controlling mechanisms of provenance change in the northern SCS, based on the results recovered by $R_{A K}$ and $R_{K C N}$, we suggest that the sediment provenance change on the northern SCS slope reflects the

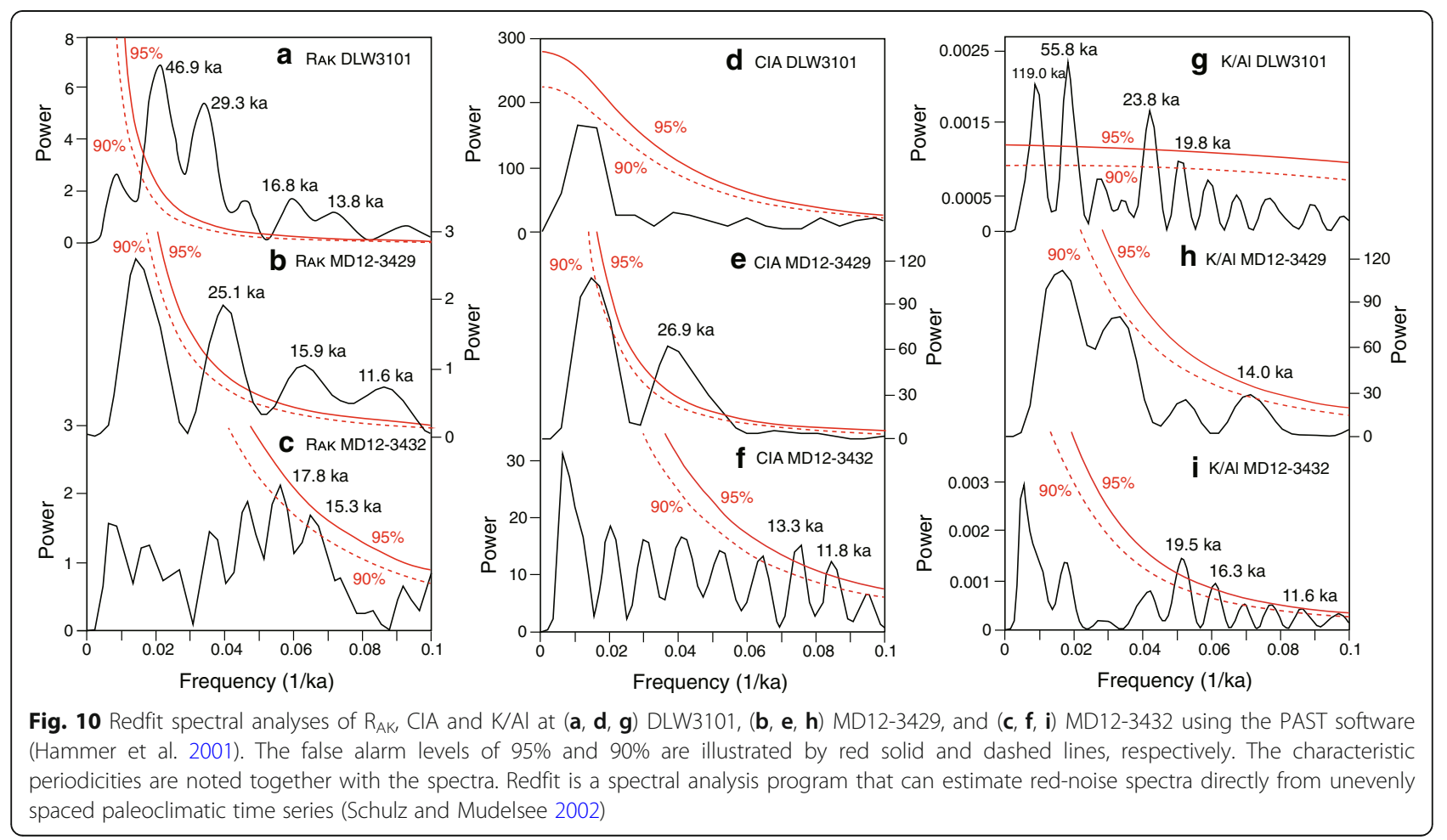


superimposition of the influences of sea level fluctuations and the East Asian summer monsoon (EASM) rainfall.

During high sea level stages, the influence of Taiwan sediment input is greater at DLW3101, MD12-3429 and MD12-3432 (Fig. 11a), while ZHS-176 shows no obvious signs of increasing Taiwan input during the whole Holocene (Fig. 8c). Most of the sediments are transported by contour currents during the high sea level stages (Fig. 11a) (Liu et al. 2017). Site ZHS-176 is located within the range of the Intermediate Water Current (IWC) (Wang et al. 2013; Sun et al. 2016; Zhao et al. 2015), which cannot carry sediments from Taiwan to the study area because of its NE flow direction. The Taiwan sediments are mainly carried by the South China Sea Branch of Kuroshio Current (SCSBKC) and Deep Water Current (DWC), while the IWC can transport sediments from Hainan, the Red River, or the Indochina Peninsula $\mathrm{CHu}$ et al. 2014). In addition, most of the sediments from the Pearl River are trapped on the continental shelf during the highstands (Ge et al. 2014), therefore Taiwan input relatively increases together with heavier rainfall due to the stronger EASM and northward shift of the ITCZ (Fig. 11a).

During low sea level stages, detrital materials at all these four sites are mainly derived from the Pearl River drainage area (Fig. 11b). When global sea level was lowered by $\sim 120 \mathrm{~m}$ during glacial maxima at approximately $137 \mathrm{ka}$ and $23 \mathrm{ka}$ (Fig. 11b), the continental shelf around the South China margin was exposed, and the distance from the Pearl River mouth to the continental slope was significantly shorter than that during high sea level stages (Huang et al. 2011; Liu et al. 2017). Meanwhile, the ITCZ can be still located near the northern SCS shelf due to the slightly southward shift (Fig. 11b) (McGee et al. 2014), hence, the rainfall can be still strong around the shelf area in glacial maxima. The detrital materials on the exposed shelf and the sediments transported by the paleo-Pearl River can be transported in abundance by downslope gravity currents (Wang et al. 2018a). In addition, the shelf sediments are subject to even higher weathering during lowstands (Wan et al. 2017). Therefore, the relative contribution of eroded detrital material with negative $R_{A K}$ values from the Pearl River or exposed shelf would increase during sea level lowstands (Fig. 11b).

It is noteworthy that more positive $R_{A K}$ values at MD12-3429 are not always coincident with higher sea level, and the change in $\mathrm{R}_{\mathrm{AK}}$ is almost opposite to that at DLW3101 during 120-82 ka (Fig. 8). Given their adjacent locations, the changes in downslope transport would affect DLW3101 and MD12-3429 similarly, so the most likely explanation would be the differences in alongslope transportation. The depth ranges of contour currents fluctuate together with sea level and seasonal change (Zhao et al. 2015; Wang et al. 2018a). The bottom boundary of the contour current SCSBKC, which carries Taiwan-sourced sediments westwards to the study area, is at $\sim 420 \mathrm{~m}$ water depth around the top of the Pearl River Canyon (Wang et al. 2018a) and $\sim 800 \mathrm{~m}$ water depth at the eastern end of Dongsha Island (Luan et al. 2012), so its depth can be deeper on the eastern side of the Pearl River Canyon due to the deeper seafloor. These indicate that MD12-3429 is located beneath the boundary between the westward SCSBKC and the eastward IWC, while DLW3101 is located in the center range of the SCSBKC. In this case, the Taiwan sediments carried by the SCSBKC may increase at DLW3101 but decrease at MD12-3429 because the sea level rise will shift the SCSBKC-IWC boundary upwards.

Temporal variations in $\mathrm{R}_{\mathrm{AK}}$ at DLW3101, MD12-3429 and MD12-3432 can present the orbital changes in sea level and the EASM (Fig. 10). The precession and semiprecession periodicities are identified in $\mathrm{R}_{\mathrm{AK}}$ values at all three sites with sufficient long records (Fig. 10). The obliquity cycles at the shallowest site DLW3101 (Fig. 10a) are most likely linked to sea level fluctuations, because the variance of global ice volume change during the Pleistocene is concentrated in the obliquity band (Huybers 2006). The precession cycles are mainly related to the EASM rainfall, which is driven by summer insolation (Huang et al. 2011). The rainfall strength variations can be indicated by oxygen isotope records from stalagmites in East and South China (Fig. 8e) (Cheng et al. 2016). Furthermore, a strong EASM is always accompanied by a warm and humid climate, which tends to enhance the river denudation rate in the Pearl River delta and Taiwan (Tamburini et al. 2003; Chen et al. 2017a).

The superposition of monsoonal and sea level changes leads to diverse patterns of sediment provenance change. On the one hand, the delivery of the Pearl River sediments to the northern SCS slope is most favoredunder the scenario of a stronger EASM and low sea level stand in other words, the combined effects of a greater denudation rate and shorter transport distance (Fig. 11b). For example, during the high rainfall periods around 57 $\mathrm{ka}$ and $31 \mathrm{ka}$, the Pearl River input is all great at DLW3101 and MD12-3432 indicated by the negative $\mathrm{R}_{\mathrm{AK}}$ values (Fig. 8a, d). On the other hand, Taiwan input is enhanced most in the presence of a stronger EASM and high sea level stand, which leads to greater erosion in Taiwan together with a stronger SCSBKC (Jiang et al. 2006). For instance, the positive $R_{A K}$ values indicate greater Taiwan input during MIS 5 at DLW3101 and MD12-3429 (Fig. 8).

In addition to sea level and monsoon rainfall, local bathymetry is another essential factor controlling sediment transport pathways on the northern SCS slope, especially 


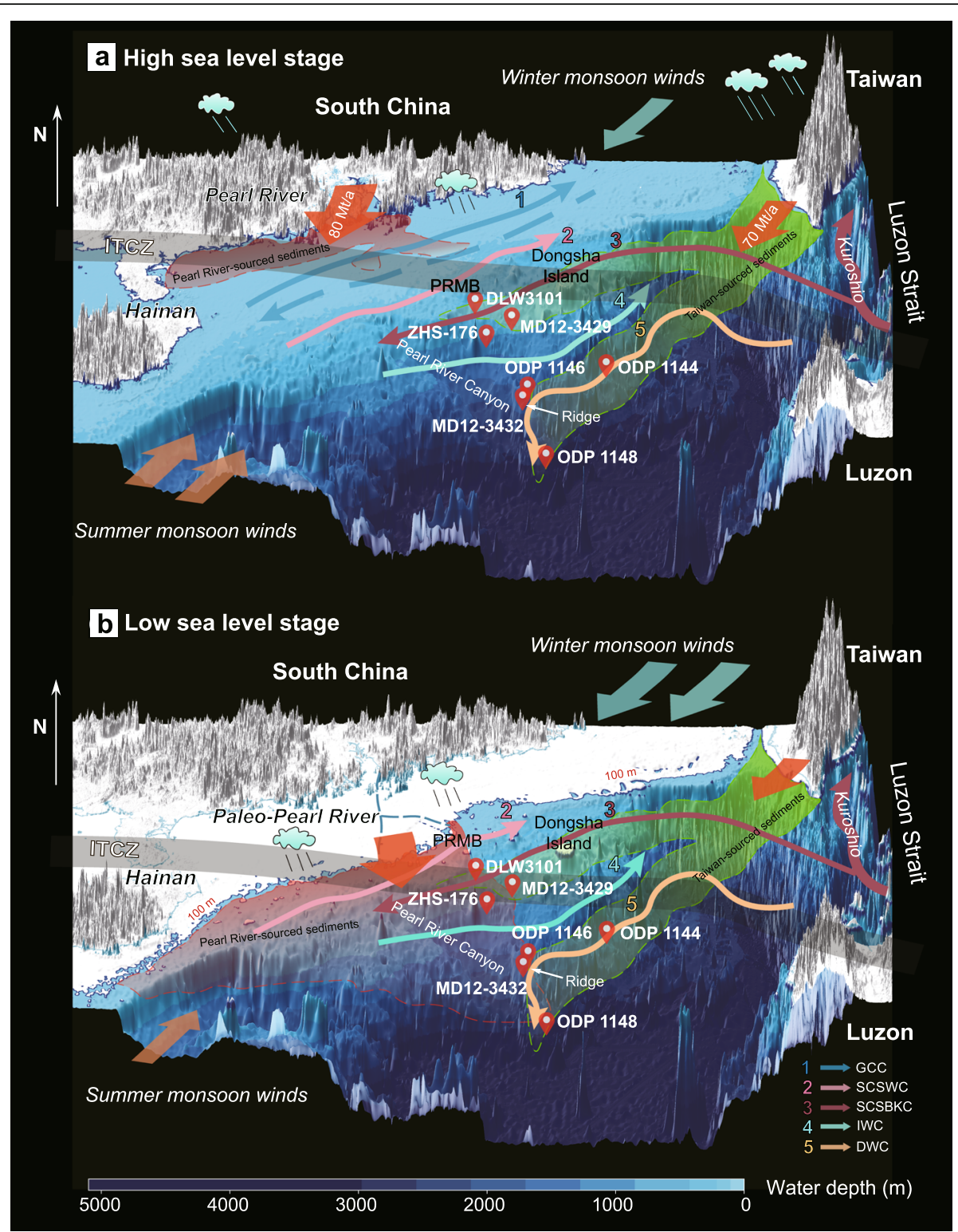

Fig. 11 Sediment depositional patterns during a high and $\mathbf{b}$ low sea level stages. The dispersal of Pearl River-sourced sediments depicted by red shaded area is wider in the glacial epochs based on our results and previous studies (Liu et al. 2016, 2017) than during the Holocene (Ge et al. 2014). The dispersal of Taiwan-sourced sediments represented by green shaded area is mainly located in the range of the SCSBKC and DWC based on our results and previous studies (Shao et al. 2007; Wan et al. 2010a; Liu et al. 2016). Gray ribbons show the locations of the ITCZ in glacial and modern times (McGee et al. 2014; Clift 2020) with the high precipitation zones noted by cloud icons. See Fig. 1 for all current systems

at MD12-3432. Sediments from ODP sites 1146 and 1148 since $3 \mathrm{Ma}$ are mainly derived from Taiwan (Wan et al. 2010a), but sediments from MD12-3432 show more similarities to the Pearl River samples (Fig. 5), although these sites are located at similar water depths and locations. The possible reason is that MD12-3432 and ODP site 1146 are respectively located on the western and eastern slopes of a ridge, which is the eastern border of the Pearl River Canyon and reaches a depth shallower than $2000 \mathrm{~m}$ (Fig. 11b). The boundary between the eastward IWC and the westward DWC may reach approximately $2000 \mathrm{~m}$ (Zhao et al. 2015), so the ridge may block the material from Taiwan in the east carried by the DWC. Meanwhile, the sediments from the Pearl River or continent shelf can be transported downslope to the west side of the ridge through the canyon system (Shanmugam 2006) (Fig. 11b). Furthermore, the exceptions appear at approximately 6-1 ka and 135-110 ka, when high sea level stands meet the strong summer monsoon, producing a more favored condition for 
Taiwan input at MD12-3432 (Fig. 8d), as the IWCDWC interface may rise during MIS 5 and the late Holocene.

\section{Conclusions}

Based on the geochemical and clay mineralogical analyses of the continental slope sediments from the northern SCS, several conclusions can be drawn concerning the sediment depositional patterns over the past $150 \mathrm{ka}$ in the northern SCS.

1) The element and mineral compositions are strongly influenced by provenance changes on the northern SCS slope. Due to the significant differences in weathering trends between the Pearl River and Taiwan sediment sources, the correlation coefficients $R_{A K}$ and $R_{K C N}$ between the endmembers on the A$\mathrm{CN}-\mathrm{K}$ diagram can be useful proxies for provenance tracing, since they are independent of hydraulic sorting and chemical weathering impacts.

2) The element and clay mineral analyses reveal that the four sites (DLW3101, MD12-3429, ZHS176 , and MD12-3432) encompassing the upper to lower slope ranges experienced similar depositional patterns during low sea level stages at approximately $137 \mathrm{ka}$ and $23 \mathrm{ka}$, when most of the detrital materials were supplied by the PaleoPearl River drainage system through gravity flows; during the high sea level stage at approximately $123 \mathrm{ka}$, the sediments were mainly supplied from Taiwan by the contour currents SCSBKC and DWC to the upper and lower slopes, respectively. And the Taiwan input was insignificant on the middle slope in the range of the contour current IWC.

3) Sea level and the EASM rainfall are the two major factors controlling sediment transport processes since $150 \mathrm{ka}$. The sea level fluctuations can significantly influence the transport distance of sediments from South China and the boundaries of contour currents, while the EASM rainfall strongly alters the erosion rates in terrestrial source regions. Besides, local bathymetry may be another essential factor affecting sediment deposition due to its impact on contour current flow direction.

\footnotetext{
Abbreviations

BP: Before present; CIA: Chemical index of alteration; DWC: Deep Water Current; EASM: East Asian summer monsoon; GCC: Guangdong Coastal Current; ICPOES: Inductively coupled plasma-optical emission; ITCZ: Intertropical Convergence Zone; IWC: Intermediate Water Current; LGP: Last Glacial Period; LGM: Last Glacial Maximum; LSRs: Linear sedimentation rates; MIS: Marine isotope stage; Mt: Million metric tons; Mz: Mean grain size; PRMB: Pearl River Mouth Basin; SCS: South China Sea; SCSBKC: South China Sea Branch of Kuroshio Current; SCSWC: South China Sea Warm Current; XRD: X-ray diffraction
}

\section{Acknowledgements}

We are grateful to the captains, scientists, officers, and crew of the R.V. Marion Dufresne for their cooperation in collecting sediment cores during the CIRCEA cruise in 2012 and the exploration cruise of Offshore Oil 708 in 2014. Yi-Jie Wang (Tongji University) is appreciated for her contribution in clay mineral analyses. Jiang-Hui Du (Eidgenössische Technische Hochschule Zürich) and Shi-Ming Wan (Institute of Oceanology, Chinese Academy of Sciences) are appreciated for their constructive comments that help to improve this paper.

\section{Authors' contributions}

$\mathrm{ZH}$ and $\mathrm{BQH}$ conceived the idea of the study. $\mathrm{ZH}$ and $\mathrm{BQH}$ selected samples. $\mathrm{ZH}$ did analytical testing. $\mathrm{ZH}$ and $\mathrm{BQH}$ interpreted the results and wrote the paper. LL and NW revised the manuscript and improved the language. All authors read and approved the final manuscript.

\section{Funding}

National Natural Science Foundation of China $(41376043$, 41876061), and Guangdong Basic and Applied Basic Research Foundation (2019A1515110896).

\section{Availability of data and materials}

The data analyzed during the current study are available in the PANGAEA repository, https://doi.org/10.1594/PANGAEA.922489.

\section{Declaration}

\section{Competing interests}

The authors declare that they have no competing interests.

\section{Author details}

'Key Laboratory of Orogenic Belts and Crustal Evolution, MOE, School of Earth and Space Sciences, Peking University, Beijing 100871, China. ${ }^{2}$ Marine Engineering Environment Center, First Institute of Oceanography, Ministry of Natural Resources, Qingdao 266061, Shandong Province, China. ${ }^{3}$ School of Urban Planning and Design, Shenzhen Graduate School, Peking University, Shenzhen 518055, Guangdong Province, China.

Received: 28 October 2020 Accepted: 12 July 2021

Published online: 28 July 2021

\section{References}

Andrews, J.E., P. Brimblecombe, T.D. Jickells, P.S. Liss, and B. Reid. 2003. An Introduction to Environmental Chemistry. 2nd ed, pp. 104-110. New York: Wiley.

Berger, A., and M.F. Loutre. 1991. Insolation values for the climate of the last 10 million years. Quaternary Science Reviews 10 (4): 297-317. https://doi. org/10.1016/0277-3791(91)90033-Q.

Boulay, S., C. Colin, A. Trentesaux, N. Frank, and Z. Liu. 2005. Sediment sources and east Asian monsoon intensity over the last $450 \mathrm{ky}$. Mineralogical and geochemical investigations on South China Sea sediments. Palaeogeography, Palaeoclimatology, Palaeoecology 228 (3-4): 260-277. https://doi.org/10.1016/j.palaeo.2005.06.005.

Cao, L., J.G. Liu, X.F. Shi, W. He, and Z. Chen. 2019. Source-to-sink processes of fluvial sediments in the northern South China Sea: Constraints from river sediments in the coastal region of South China. Journal of Asian Earth Sciences 185: 104020. https://doi.org/10.1016/j.jseaes.2019.104020.

Chen, C.H., and T. Lee. 1990. A Nd-Sr isotopic study on river sediments of Taiwan. Proceedings of the Geological Society of China 33 (4): 339-350.

Chen, H., X.N. Xie, D. Van Rooij, T. Vandorpe, M. Su, and D.X. Wang. 2014 Depositional characteristics and processes of alongslope currents related to a seamount on the northwestern margin of the northwest Sub-Basin, South China Sea. Marine Geology 355: 36-53. https://doi.org/1 0.1016/j.margeo.2014.05.008

Chen, Q., C. Kissel, and Z.F. Liu. 2017b. Late Quaternary climatic forcing on the terrigenous supply in the northern South China Sea: Input from magnetic studies. Earth and Planetary Science Letters 471: 160-171. https://doi.org/10.1016/j.epsl.2017.04.047.

Chen, Q., Z.F. Liu, and C. Kissel. 2017a. Clay mineralogical and geochemical proxies of the east Asian summer monsoon evolution in the South 
China Sea during Late Quaternary. Scientific Reports 7 (1): 42083. https:// doi.org/10.1038/srep42083.

Cheng, H., R.L. Edwards, A. Sinha, C. Spötl, L. Yi, S.T. Chen, M. Kelly, G. Kathayat, X.F. Wang, X.L. Li, X.G. Kong, Y.J. Wang, Y.F. Ning, and H.W. Zhang. 2016. The Asian monsoon over the past 640,000 years and ice age terminations. Nature 534 (7609): 640-646. https://doi.org/10.1038/na ture18591.

Clift, P., J.I. Lee, M.K. Clark, and J. Blusztajn. 2002. Erosional response of South China to arc rifting and monsoonal strengthening; a record from the South China Sea. Marine Geology 184 (3-4): 207-226. https://doi.org/10.1 016/S0025-3227(01)00301-2.

Clift, P.D. 2006. Controls on the erosion of Cenozoic Asia and the flux of clastic sediment to the ocean. Earth and Planetary Science Letters 241 (3-4): 571-580. https://doi.org/10.1016/j.epsl.2005.11.028.

Clift, P.D. 2020. Asian monsoon dynamics and sediment transport in SE Asia. Journal of Asian Earth Sciences 195: 104352. https://doi.org/10.1016/j.jsea es.2020.104352.

Clift, P.D., S.M. Wan, and J. Blusztajn. 2014. Reconstructing chemical weathering, physical erosion and monsoon intensity since $25 \mathrm{Ma}$ in the northern South China Sea: A review of competing proxies. Earth-Science Reviews 130: 86-102. https://doi.org/10.1016/j.earscirev.2014.01.002.

Fedo, C.M., H.W. Nesbitt, and G.M. Young. 1995. Unraveling the effects of potassium metasomatism in sedimentary-rocks and paleosols, with implications for paleoweathering conditions and provenance. Geology 23 (10): 921-924. https://doi.org/10.1130/0091-7613(1995)023<0921: UTEOPM > 2.3.CO;2

Ge, Q., F.Y. Chu, Z. Xue, J.P. Liu, Y.S. Du, and Y.X. Fang. 2010. Paleoenvironmental records from the northern South China Sea since the last glacial maximum. Acta Oceanologica Sinica 29 (3): 46-62. https://doi.org/10.1007/s13131-010-0036-9.

Ge, Q. J.P. Liu, Z. Xue, and F.Y. Chu. 2014. Dispersal of the Zhujiang River (Pearl River) derived sediment in the Holocene. Acta Oceanologica Sinica 33 (8): 1-9. https://doi.org/10.1007/s13131-014-0407-8.

Gong, C.L., Y.M. Wang, W.L. Zhu, W.G. Li, and Q. Xu. 2013. Upper Miocene to quaternary unidirectionally migrating deep-water channels in the Pearl River Mouth Basin, northern South China Sea. AAPG Bulletin 97 (2): 285 308. https://doi.org/10.1306/07121211159.

Gonneea, M.E., and A. Paytan. 2006. Phase associations of barium in marine sediments. Marine Chemistry 100 (1): 124-135. https://doi.org/10.1016/j. marchem.2005.12.003.

Hammer, Ø., D.A.T. Harper, and P.D. Ryan. 2001. PAST: Paleontological statistics software package for education and data analysis. Palaeontologia Electronica 4 (1): 1-9.

Hatano, N., K. Yoshida, and E. Sasao. 2019. Effects of grain size on the chemical weathering index: A case study of Neogene fluvial sediments in Southwest Japan. Sedimentary Geology 386: 1-8. https://doi.org/10.1 016/j.sedgeo.2019.03.017.

Hu, B.Q., J. Li, R.Y. Cui, H.L. Wei, J.T. Zhao, G.G. Li, X.S. Fang, X. Ding, L. Zou, and F.L. Bai. 2014. Clay mineralogy of the riverine sediments of Hainan Island, South China Sea: Implications for weathering and provenance. Journal of Asian Earth Sciences 96: 84-92. https://doi.org/10.1016/j.jsea es.2014.08.036

Hu, D.K., P. Böning, C.M. Köhler, S. Hillier, N. Pressling, S.M. Wan, H.J. Brumsack, and P.D. Clift. 2012. Deep sea records of the continental weathering and erosion response to east Asian monsoon intensification since $14 \mathrm{ka}$ in the South China Sea. Chemical Geology 326-327: 1-18. https://doi.org/10.1016/j.chemgeo.2012.07.024.

Hu, D.K., P.D. Clift, P. Böning, R. Hannigan, S. Hillier, J. Blusztajn, S.M. Wan, and D.Q. Fuller. 2013. Holocene evolution in weathering and erosion patterns in the Pearl River delta. Geochemistry, Geophysics, Geosystems 14 (7): 2349-2368. https://doi.org/10.1002/ggge.20166.

Hu, D.K., P.D. Clift, S.M. Wan, P. Böning, R. Hannigan, S. Hillier, and J. Blusztajn 2016. Testing chemical weathering proxies in Miocene-recent fluvialderived sediments in the South China Sea. Geological Society, London, Special Publications 429 (1): 45-72. https://doi.org/10.1144/sp429.5.

Huang, J., A.C. Li, and S.M. Wan. 2011. Sensitive grain-size records of Holocene east Asian summer monsoon in sediments of northern South
China Sea slope. Quaternary Research 75 (3): 734-744. https://doi.org/1 0.1016/j.yqres.2011.03.002.

Huang, J., S.M. Wan, Z.F. Xiong, D.B. Zhao, X.T. Liu, A.C. Li, and T.G. Li. 2016. Geochemical records of Taiwan-sourced sediments in the South China Sea linked to Holocene climate changes. Palaeogeography, Palaeoclimatology, Palaeoecology 441: 871-881. https://doi.org/10.1016/j. palaeo.2015.10.036.

Huang, W., and P.X. Wang. 2006. Sediment mass and distribution in the South China Sea since the Oligocene. Science in China Series D: Earth Sciences 49 (11): 1147-1155. https://doi.org/10.1007/s11430-006-2019-4.

Huybers, P. 2006. Early Pleistocene glacial cycles and the integrated summer insolation forcing. Science 313 (5786): 508-511. https://doi.org/10.1126/ science.1125249.

Israeli, Y., and S. Emmanuel. 2018. Impact of grain size and rock composition on simulated rock weathering. Earth Surface Dynamics 6 (2): 319-327. https://doi.org/10.5194/esurf-6-319-2018.

Jiang, H., S. Björck, L.H. Ran, Y. Huang, and J.Y. Li. 2006. Impact of the Kuroshio current on the South China Sea based on a 115000 year diatom record. Journal of Quaternary Science 21 (4): 377-385. https://doi. org/10.1002/jas.1000.

Kissel, C., Z. Jian, and H. Leau. 2012. MD190-CIRCEA cruise report, les rapports de cam-pagne à la mer. Brest: Institut polaire français Paul-Émile Victor.

Lan, C.Y., C.S. Lee, J.J.S. Shen, C.Y. Lu, S.A. Mertzman, and T.W. Wu. 2002. Nd$\mathrm{Sr}$ isotopic composition and geochemistry of sediments from Taiwan and their implications. Western Pacific Earth Sciences 2 (2): 205-222.

Leleyter, L., C. Rousseau, L. Biree, and F. Baraud. 2012. Comparison of EDTA, $\mathrm{HCl}$ and sequential extraction procedures, for selected metals ( $\mathrm{cu}, \mathrm{Mn}$, $\mathrm{Pb}, \mathrm{Zn}$ ), in soils, riverine and marine sediments. Journal of Geochemical Exploration 116: 51-59. https://doi.org/10.1016/j.gexplo.2012.03.006.

Li, H., B.Q. Huang, and N. Wang. 2017. Changes of the palaeo-sea surface productivity and bottom water dissolved oxygen content at MD123429, northern South China Sea. Acta Palaeontologica Sinica 56 (2): 238248. https://doi.org/10.19800/j.cnki.aps.2017.02.010 (in Chinese with English abstract).

Lisiecki, L.E., and M.E. Raymo. 2005. A Pliocene-Pleistocene stack of 57 globally distributed benthic $\delta^{18} \mathrm{O}$ records. Paleoceanography 20 (1): PA1003. https://doi.org/10.1029/2004PA001071.

Liu, B.L., Y.P. Wang, X. Su, and H.Y. Zheng. 2013. Elemental geochemistry of northern slope sediments from the South China Sea: Implications for provenance and source area weathering since Early Miocene. Geochemistry 73 (1): 61-74. https://doi.org/10.1016/j.chemer.2012.11.005.

Liu, J.G., S. Steinke, C. Vogt, M. Mohtadi, R. De Pol-Holz, and D. Hebbeln 2017. Temporal and spatial patterns of sediment deposition in the northern South China Sea over the last 50,000 years. Palaeogeography, Palaeoclimatology, Palaeoecology 465: 212-224. https://doi.org/10.1016/j. palaeo.2016.10.033.

Liu, J.G., R. Xiang, M.H. Chen, Z. Chen, W. Yan, and F. Liu. 2011. Influence of the Kuroshio current intrusion on depositional environment in the northern South China Sea: Evidence from surface sediment records. Marine Geology 285 (1-4): 59-68. https://doi.org/10.1016/j.margeo.2011. 05.010.

Liu, J.P., C.S. Liu, K.H. Xu, J.D. Milliman, J.K. Chiu, S.J. Kao, and S.W. Lin. 2008. Flux and fate of small mountainous rivers derived sediments into the Taiwan Strait. Marine Geology 256 (1-4): 65-76. https://doi.org/10.1016/j. margeo.2008.09.007.

Liu, Z.F., C. Colin, W. Huang, K.P. Le, S.Q. Tong, Z. Chen, and A. Trentesaux. 2007. Climatic and tectonic controls on weathering in south China and Indochina Peninsula: Clay mineralogical and geochemical investigations from the Pearl, Red, and Mekong drainage basins. Geochemistry, Geophysics, Geosystems 8 (5): Q05005. https://doi.org/10.1029/2006GC001490.

Liu, Z.F., C. Colin, X.J. Li, Y.L. Zhao, S.T. Tuo, Z. Chen, F.P. Siringan, J.T. Liu, C.Y. Huang, C.F. You, and K.F. Huang. 2010. Clay mineral distribution in surface sediments of the northeastern South China Sea and surrounding fluvial drainage basins: Source and transport. Marine Geology 277 (1): 48-60. https://doi.org/10.1016/j.margeo.2010.08.010.

Liu, Z.F., A. Trentesaux, S.C. Clemens, C. Colin, P.X. Wang, B.Q. Huang, and S. Boulay. 2003b. Clay mineral assemblages in the northern South China Sea: 
Implications for east Asian monsoon evolution over the past 2 million years. Marine Geology 201 (1): 133-146. https://doi.org/10.1016/S0025-322 7(03)00213-5.

Liu, Z.F., A. Trentesaux, S.C. Clemens, and P.X. Wang. 2003a. Quaternary clay mineralogy in the northern South China Sea (ODP site 1146). Science in China Series D: Earth Sciences 46 (12): 1223-1235. https://doi.org/10.13 60/02yd0107.

Liu, Z.F., Y.L. Zhao, C. Colin, F.P. Siringan, and Q. Wu. 2009. Chemical weathering in Luzon, Philippines from clay mineralogy and majorelement geochemistry of river sediments. Applied Geochemistry 24 (11): 2195-2205. https://doi.org/10.1016/j.apgeochem.2009.09.025.

Liu, Z.F., Y.L. Zhao, C. Colin, K. Stattegger, M.G. Wiesner, C. Huh, Y.W. Zhang, XJ. Li, P. Sompongchaiyakul, C.F. You, C.Y. Huang, J.T. Liu, F.P. Siringan, K.P. Le, E. Sathiamurthy, W.S. Hantoro, J.G. Liu, S.T. Tuo, S.H. Zhao, S.W. Zhou, Z.D. He, Y. C. Wang, S. Bunsomboonsakul, and Y.L. Li. 2016. Source-to-sink transport processes of fluvial sediments in the South China Sea. Earth-Science Reviews 153: 238-273. https://doi.org/10.1016/j.earscirev.2015.08.005.

Luan, X.W., L. Zhang, and X.C. Peng. 2012. Dongsha erosive channel on northern South China Sea shelf and its induced Kuroshio South China Sea branch. Science China Earth Sciences 55 (1): 149-158. https://doi. org/10.1007/s11430-011-4322-y.

McGee, D., A. Donohoe, J. Marshall, and D. Ferreira. 2014. Changes in ITCZ location and cross-equatorial heat transport at the last glacial maximum, Heinrich Stadial 1, and the mid-Holocene. Earth and Planetary Science Letters 390: 69-79. https://doi.org/10.1016/..epsl.2013.12.043.

Milliman, J.D., and K.L. Farnsworth. 2011. River discharge to the Coastal Ocean: A global synthesis. Cambridge: Cambridge University Press. https://doi.org/10.1017/CBO9780511781247.

Nan, F., H.J. Xue, and F. Yu. 2015. Kuroshio intrusion into the South China Sea: A review. Progress in Oceanography 137: 314-333. https://doi.org/1 0.1016/j.pocean.2014.05.012

Nesbitt, H.W., and G.M. Young. 1982. Early Proterozoic climates and plate motions inferred from major element chemistry of lutites. Nature 299 (5885): 715-717. https://doi.org/10.1038/299715a0.

Nesbitt, H.W., and G.M. Young. 1984. Prediction of some weathering trends of plutonic and volcanic rocks based on thermodynamic and kinetic considerations. Geochimica et Cosmochimica Acta 48 (7): 1523-1534. https://doi.org/10.1016/0016-7037(84)90408-3.

Nesbitt, H.W., and G.M. Young. 1989. Formation and diagenesis of weathering profiles. The Journal of Geology 97 (2): 129-147. https://doi. org/10.1086/629290.

Qiu, Y., L. Li, C.T.A. Chen, X.G. Guo, and C.S. Jing. 2011. Currents in the Taiwan Strait as observed by surface drifters. Journal of Oceanography 67 (4): 395-404. https://doi.org/10.1007/s10872-011-0033-4.

Qu, H.X., and B.Q. Huang. 2019. Paleoclimate change reflected by element ratios of terrigenous sediments from deep-sea oxygen isotope MIS6 to MIS5 at MD12-3432 station in northern South China Sea. Earth Science Frontiers 26 (3): 236-242. https://doi.org/10.13745/j.esf.sf.2019.4.18 (in Chinese with English abstract).

Qu, T.D., J.B. Girton, and J.A. Whitehead. 2006. Deepwater overflow through Luzon Strait. Journal of Geophysical Research: Oceans 111 (C1). https:// doi.org/10.1029/2005JC003139.

Schulz, M., and M. Mudelsee. 2002. REDFIT: Estimating red-noise spectra directly from unevenly spaced paleoclimatic time series. Computers \& Geosciences 28 (3): 421-426. https://doi.org/10.1016/50098-3004(01)00044-9.

Selvaraj, K., and C.T.A. Chen. 2006. Moderate chemical weathering of subtropical Taiwan: Constraints from solid-phase geochemistry of sediments and sedimentary rocks. The Journal of Geology 114 (1): 101116. https://doi.org/10.1086/498102.

Shanmugam, G. 2006. The tsunamite problem. Journal of Sedimentary Research 76 (5): 718-730. https://doi.org/10.2110/jsr.2006.073.

Shao, L., Y.C. Cui, K. Stattegger, W.L. Zhu, P.J. Qiao, and Z.G. Zhao. 2019. Drainage control of Eocene to Miocene sedimentary records in the southeastern margin of Eurasian plate. GSA Bulletin 131 (3-4): 461-478. https://doi.org/10.1130/B32053.1.

Shao, L., X.J. Li, J.H. Geng, X. Pang, Y.C. Lei, P.J. Qiao, L.L. Wang, and H.B. Wang. 2007. Deep water bottom current deposition in the northern
South China Sea. Science in China Series D: Earth Sciences 50 (7): 10601066. https://doi.org/10.1007/s11430-007-0015-y.

Shao, L., P.J. Qiao, X. Pang, G.J. Wei, Q.Y. Li, W.L. Miao, and A. Li. 2008. Nd isotopic variations and its implications in the recent sediments from the northern South China Sea. Chinese Science Bulletin 54 (2): 311-317. https://doi.org/10.1007/s11434-008-0453-8.

Shaw, P.T., and S.Y. Chao. 1994. Surface circulation in the South China Sea. Deep Sea Research Part I: Oceanographic Research Papers 41 (11): $1663-$ 1683. https://doi.org/10.1016/0967-0637(94)90067-1.

Spratt, R.M., and L.E. Lisiecki. 2016. A late Pleistocene sea level stack. Climate of the Past 12 (4): 1079-1092. https://doi.org/10.5194/cp-12-1079-2016.

Sun, Q.L., J. Cartwright, S.G. Wu, G.F. Zhong, S.H. Wang, and H.L. Zhang. 2016. Submarine erosional troughs in the northern South China Sea: Evidence for Early Miocene Deepwater circulation and paleoceanographic change. Marine and Petroleum Geology 77: 75-91. https://doi.org/10.1016/.marpetgeo.2016.06.005.

Tamburini, F., T. Adatte, K. Föllmi, S.M. Bernasconi, and P. Steinmann. 2003. Investigating the history of east Asian monsoon and climate during the last glacial-interglacial period (0-140000 years): Mineralogy and geochemistry of ODP sites 1143 and 1144, South China Sea. Marine Geology 201 (1): 147-168. https://doi.org/10.1016/50025-3227(03)00214-7.

Tribovillard, N., T.J. Algeo, T. Lyons, and A. Riboulleau. 2006. Trace metals as paleoredox and paleoproductivity proxies: An update. Chemical Geology 232 (1-2): 12-32. https://doi.org/10.1016/j.chemgeo.2006.02.012.

Wan, S.M., P.D. Clift, A.C. Li, T.G. Li, and X.B. Yin. 2010b. Geochemical records in the South China Sea: Implications for east Asian summer monsoon evolution over the last 20 Ma. Geological Society, London, Special Publications 342 (1): 245-263. https://doi.org/10.1144/sp342.14.

Wan, S.M., P.D. Clift, D.B. Zhao, N. Hovius, G. Munhoven, C. France-Lanord, Y. X. Wang, Z.F. Xiong, J. Huang, Z.J. Yu, J. Zhang, W.T. Ma, G.L. Zhang, A.C. Li, and T.G. Li. 2017. Enhanced silicate weathering of tropical shelf sediments exposed during glacial lowstands: A sink for atmospheric $\mathrm{CO}_{2}$. Geochimica et Cosmochimica Acta 200: 123-144. https://doi.org/1 0.1016/j.gca.2016.12.010.

Wan, S.M., A.C. Li, P.D. Clift, and J.B.W. Stuut. 2007. Development of the east Asian monsoon: Mineralogical and sedimentologic records in the northern South China Sea since $20 \mathrm{Ma}$. Palaeogeography, Palaeoclimatology, Palaeoecology 254 (3-4): 561-582. https://doi.org/10.1016/.jpalaeo.2007.07.009.

Wan, S.M., A.C. Li, P.D. Clift, S.G. Wu, K.H. Xu, and T.G. Li. 2010a. Increased contribution of terrigenous supply from Taiwan to the northern South China Sea since 3 Ma. Marine Geology 278 (1): 115-121. https://doi.org/1 0.1016/j.margeo.2010.09.008.

Wan, S.M., L. Qin, S.Y. Yang, D.B. Zhao, J. Zhang, D.F. Jiao, G.Q. Cai, W.Q. Pei, H.M. Gong, Z.K. Xu, J. Huang, Z.J. Yu, H.L. Jin, A.C. Li, and T.G. Li. 2020. South China Sea shelf weathering in glacial periods and its link to carbon cycle. Quaternary Sciences 40 (6): 1532-1549. https://doi.org/1 0.11928/j.issn.1001-7410.2020.06.14 (in Chinese with English abstract).

Wang, D.X., B. Hong, J.P. Gan, and H.Z. Xu. 2010. Numerical investigation on propulsion of the counter-wind current in the northern South China Sea in winter. Deep Sea Research Part I: Oceanographic Research Papers 57 (10): 1206-1221. https://doi.org/10.1016/j.dsr.2010.06.007.

Wang, D.X., Q. Wang, W.D. Zhou, S.Q. Cai, L. Li, and B. Hong. 2013. An analysis of the current deflection around Dongsha Islands in the northern South China Sea. Journal of Geophysical Research: Oceans 118 (1): 490-501. https://doi.org/10.1029/2012JC008429.

Wang, N., B.Q. Huang, Y.T. Dong, and X. Xie. 2018b. The evolution of Deepwater dissolved oxygen in the northern South China Sea since $400 \mathrm{ka}$. Palaeoworld 27 (2): 301-308. https://doi.org/10.1016/j.palwor.2017.11.001.

Wang, X.X., H.T. Zhuo, Y.M. Wang, P.X. Mao, M. He, W.T. Chen, J.W. Zhou, S. M. Gao, and M.H. Wang. 2018a. Controls of contour currents on intracanyon mixed sedimentary processes: Insights from the Pearl River canyon, northern South China Sea. Marine Geology 406: 193-213. https://doi.org/10.1016/j.margeo.2018.09.016.

Wei, G.J., X.H. Li, Y. Liu, L. Shao, and X.R. Liang. 2006. Geochemical record of chemical weathering and monsoon climate change since the early Miocene in the South China Sea. Paleoceanography 21 (4): PA4214. https://doi.org/10.1029/2006PA001300. 
Wei, G.J., Y. Liu, X.H. Li, L. Shao, and X.R. Liang. 2003. Climatic impact on Al, K, SC and Ti in marine sediments: Evidence from ODP site 1144, South China Sea. Geochemical Journal 37 (5): 593-602. https://doi.org/10.2343/ geochemj.37.593.

Wei, G.J., Y. Liu, J.L. Ma, L.H. Xie, J.F. Chen, W.F. Deng, and S. Tang. 2012. Nd, $\mathrm{Sr}$ isotopes and elemental geochemistry of surface sediments from the South China Sea: Implications for provenance tracing. Marine Geology 319-322: 21-34. https://doi.org/10.1016/j.margeo.2012.05.007.

Xiong, S.F., Z.L. Ding, Y.J. Zhu, R. Zhou, and H.J. Lu. 2010. A 6 Ma chemical weathering history, the grain size dependence of chemical weathering intensity, and its implications for provenance change of the Chinese loess-red clay deposit. Quaternary Science Reviews 29 (15-16): 19111922. https://doi.org/10.1016/j.quascirev.2010.04.009.

Zhang, H., L. Shao, G.C. Zhang, Y.C. Cui, Z.G. Zhao, and Y.L. Hou. 2020. The response of Cenozoic sedimentary evolution coupled with the formation of the South China Sea. Geological Journal 55 (10): 6989-7010. https://doi.org/10.1002/gj.3856.

Zhang, J., X.W. Meng, and X.Q. Wang. 2013. The record of major element ratios in Late Quaternary at northern slope of the South China Sea and its indicative significance on the cooling events. Acta Oceanologica Sinica 35 (4): 106-111. https://doi.org/10.3969/j.issn.0253-4193.2013.04. 013 (in Chinese with English abstract).

Zhao, D.B., S.M. Wan, P.D. Clift, R. Tada, J. Huang, X.B. Yin, R.Q. Liao, X.Y. Shen, X.F. Shi, and A.C. Li. 2018. Provenance, sea-level and monsoon climate controls on silicate weathering of Yellow River sediment in the northern Okinawa trough during late last glaciation. Palaeogeography, Palaeoclimatology, Palaeoecology 490: 227-239. https://doi.org/10.1016/j. palaeo.2017.11.002.

Zhao, W., C. Zhou, J.W. Tian, Q.X. Yang, B. Wang, L.L. Xie, and T.D. Qu. 2014. Deep water circulation in the Luzon Strait. Journal of Geophysical Research: Oceans 119 (2): 790-804. https://doi.org/10.1002/2013 JC009587.

Zhao, Y.L., Z.F. Liu, Y.W. Zhang, J.R. Li, M. Wang, W.G. Wang, and J.P. Xu. 2015. In situ observation of contour currents in the northern South China Sea: Applications for Deepwater sediment transport. Earth and Planetary Science Letters 430: 477-485. https://doi.org/10.1016/j.epsl.2015. 09.008.

Zhong, Y., Z. Chen, L. Li, J.G. Liu, G. Li, X.F. Zheng, S.H. Wang, and A.B. Mo. 2017. Bottom water hydrodynamic provinces and transport patterns of the northern South China Sea: Evidence from grain size of the terrigenous sediments. Continental Shelf Research 140: 11-26. https://doi. org/10.1016/j.csr.2017.01.023.

Zhou, H., L.J. Liu, Y.Q. Xu, Q.J. Zhou, and S. Gao. 2018. Sediment characteristics and paleoenvironmental significance of Core DLW3101 from northern slope of the South China Sea. Acta Oceanologica Sinica 40 (7): 103-115. https://doi.org/10.3969/j.issn.0253-4193.2018.07.009 (in Chinese with English abstract).

Zhou, W.J., X.F. Lu, Z.K. Wu, L. Deng, A.J.T. Jull, D. Donahue, and W. Beck. 2002. Peat record reflecting Holocene climatic change in the Zoigê plateau and AMS radiocarbon dating. Chinese Science Bulletin 47 (1): 66-70. https://doi.org/10.1360/02tb9013.

Zhu, M.Z., S. Graham, X. Pang, and T. McHargue. 2010. Characteristics of migrating submarine canyons from the middle Miocene to present: Implications for paleoceanographic circulation, northern South China Sea. Marine and Petroleum Geology 27 (1): 307-319. https://doi.org/10.1 016/j.marpetgeo.2009.05.005.

\section{Publisher's Note}

Springer Nature remains neutral with regard to jurisdictional claims in published maps and institutional affiliations.

\section{Submit your manuscript to a SpringerOpen ${ }^{\circ}$ journal and benefit from:}

- Convenient online submission

- Rigorous peer review

- Open access: articles freely available online

- High visibility within the field

- Retaining the copyright to your article

Submit your next manuscript at $\boldsymbol{\nabla}$ springeropen.com 